\title{
Synthesis of Silver Nanoparticles Mediated by Fungi: A Review
}

\author{
Mariana Guilger-Casagrande and Renata de Lima* \\ Laboratory for Evaluation of the Bioactivity and Toxicology of Nanomaterials, University of Sorocaba, Sorocaba, Brazil
}

OPEN ACCESS

Edited by:

Jinmyoung Joo,

Ulsan National Institute of Science and

Technology, South Korea

Reviewed by:

Pradipta Ranjan Rauta,

University of Texas MD Anderson

Cancer Center, United States

Palanivel Velmurugan,

Sri Sankara Arts and Science

College, India

*Correspondence:

Renata de Lima

renata.lima@prof.uniso.br

Specialty section:

This article was submitted to

Nanobiotechnology,

a section of the journal

Frontiers in Bioengineering and

Biotechnology

Received: 19 July 2019

Accepted: 07 October 2019

Published: 22 October 2019

Citation:

Guilger-Casagrande $M$ and Lima $R$ (2019) Synthesis of Silver Nanoparticles Mediated by Fungi: A

Review.

Front. Bioeng. Biotechnol. 7:287.

doi: 10.3389/fbioe.2019.00287
The use of fungi as reducing and stabilizing agents in the biogenic synthesis of silver nanoparticles is attractive due to the production of large quantities of proteins, high yields, easy handling, and low toxicity of the residues. Furthermore, this synthesis process coats the nanoparticles with biomolecules derived from the fungus, which can improve stability and may confer biological activity. The aim of this review is to describe studies in which silver nanoparticles were synthesized using fungi as reducing agents, discussing the mechanisms and optimization of the synthesis, as well as the applications. The literature shows that various species of fungus have potential for use in biogenic synthesis, enabling the production of nanoparticles with different characteristics, considering aspects such as their size, surface charge, and morphology. The synthesis mechanisms have not yet been fully elucidated, although it is believed that fungal biomolecules are mainly responsible for the process. The synthesis can be optimized by adjusting parameters such as temperature, $\mathrm{pH}$, silver precursor concentration, biomass amount, and fungus cultivation time. Silver nanoparticles synthesized using fungi enable the control of pathogens, with low toxicity and good biocompatibility. These findings open perspectives for future investigations concerning the use of these nanoparticles as antimicrobials in the areas of health and agriculture.

Keywords: biogenic synthesis, silver nanoparticles, fungi, biological activity, biomolecules

\section{INTRODUCTION}

Among the different types of metallic nanoparticles, silver nanoparticles can be highlighted for their broad-spectrum antimicrobial potential (Prabhu and Poulose, 2012; Rai et al., 2014; Gupta et al., 2017; Loo et al., 2018). These nanoparticles adhere to the cell walls and membranes of microorganisms and may reach the cell interior. They damage the cellular structures, induce the production of reactive oxygen species, and alter the mechanisms of signal transduction (Kim et al., 2011; Dakal et al., 2016). Several studies report applications in which good results have been obtained using silver nanoparticles for the control of pathogenic microorganisms in the areas of health and agriculture (Kim et al., 2012; Mishra and Singh, 2015; Burduşel et al., 2018).

The commonest method used to produce silver nanoparticles is chemical synthesis, employing reagents whose function is to reduce the silver ions and stabilize the nanoparticles. These reagents are toxic and can present risks to health and the environment (Ahmed et al., 2016; Zhang et al., 2016), which has led to increasing interest in biogenic synthesis methods. Such processes enable nanoparticles to be obtained that present lower toxicity, better physicochemical characteristics, and higher stability (Iravani et al., 2014).

Biogenic synthesis of nanoparticles can be performed using organisms such as bacteria, fungi, and plants, or the byproducts of their metabolism, which act as reducing and stabilizing agents 
(Durán et al., 2011). These nanoparticles are capped with biomolecules derived from the organism used in the synthesis, which can improve stability and may present biological activity (Ballotin et al., 2016). Biogenic synthesis is relatively simple, clean, sustainable, and economical, and provides greater biocompatibility in the uses of nanoparticles (Gholami-Shabani et al., 2014).

The synthesis of silver nanoparticles using bacteria involves cultivating the organisms in a suitable medium, followed by contact of the bacteria or their metabolites with a silver nitrate (AgNO3) solution (Singh et al., 2015). When the synthesis is performed using plants, aqueous extracts are prepared from the leaves, stems, or roots, followed by the addition of silver nitrate solution (Rheder et al., 2018). The use of fungi to synthesize silver nanoparticles involves culturing the fungus on agar, followed by transfer to a liquid medium. The biomass produced is subsequently transferred to water for release of the compounds that act in the synthesis. After filtration, the biomass is discarded and silver nitrate is added to the filtrate (Costa Silva et al., 2017; Guilger et al., 2017; Mekkawy et al., 2017; Ottoni et al., 2017).

The purpose of this review is to provide an overview of the main published studies concerning the use of fungi for the biogenic synthesis of silver nanoparticles, as well as the applications of these materials in different areas. The synthesis mechanisms are discussed, together with methods to optimize the processes and the importance of cappings on the nanoparticles.

Given the problems caused by pathogenic microorganisms, there is a continuing search for more effective techniques for their control. The emergence of nanotechnology has led to increasing interest in the antimicrobial properties of silver nanoparticles and in exploring environmentally friendly ways in which they can be used most effectively.

\section{BIOGENIC SYNTHESIS OF SILVER NANOPARTICLES}

Most of the conventional methods used to produce nanoparticles have disadvantages such as the use of toxic chemicals and the generation of waste, which can cause environmental pollution (Iravani et al., 2014; Ahmed et al., 2016). Consequently, in recent years there has been increasing interest in eco-friendly synthesis methods. The methods involve the use of organisms including bacteria, fungi, and plants, which can reduce metal salts and enable the formation of nanoparticles that present the desired size and morphology (Azmath et al., 2016). The production of nanoparticles by biological reduction of metals is an option that can be considered clean, non-toxic, and environmentally acceptable (Banu and Balasubramanian, 2014b).

Fungi are attractive agents for biogenic synthesis of silver nanoparticles, because they offer high tolerance to metals and are easy to handle. They also secrete large quantities of extracellular proteins that contribute to the stability of the nanoparticles (Balaji et al., 2009; Du et al., 2015; Netala et al., 2016). Advantages of fungal cultures over bacterial systems are that they provide good biomass production and do not require additional steps to extract the filtrate (Gade et al., 2008). Compared to synthesis using plants, the mycelial mass of fungi is more resistant to agitation and pressure, so it is more suitable for large-scale syntheses (Velusamy et al., 2016). Furthermore, by adjusting culture conditions such as time, temperature, $\mathrm{pH}$, and quantity of biomass, among others, it is possible to manipulate the metabolism of fungi so as to obtain nanoparticles with the desired characteristics, such as specific size and morphology (Zielonka and Klimek-Ochab, 2017).

\section{Biogenic Synthesis of Silver Nanoparticles Mediated by Fungi}

Fungi have excellent potential for the production of many compounds that can be used in different applications. Around 6,400 bioactive substances are known to be produced by microscopic filamentous fungi (ascomycetes and imperfect fungi) and other fungal species (Bérdy, 2005). These organisms are widely used as reducing and stabilizing agents, due to their heavy metal tolerance and capacity to internalize and bioaccumulate metals. Furthermore, fungi can be easily cultivated on a large scale ("nanofactories") and can produce nanoparticles with controlled size and morphology (Gade et al., 2008; Ahluwalia et al., 2014; Azmath et al., 2016; Khan et al., 2017). Fungi have advantages over other microorganisms, in that they produce large quantities of proteins and enzymes, some of which can be used for the fast and sustainable synthesis of nanoparticles (Vahabi et al., 2011; Alghuthaymi et al., 2015).

The mechanism of biogenic synthesis of nanoparticles using fungi may be intracellular or extracellular. In the case of intracellular synthesis, the metal precursor is added to the mycelial culture and is internalized in the biomass. Consequently, extraction of the nanoparticles is required after the synthesis, employing chemical treatment, centrifugation, and filtration to disrupt the biomass and release the nanoparticles (CastroLongoria et al., 2011; Rajput et al., 2016; Molnár et al., 2018). In extracellular synthesis, the metal precursor is added to the aqueous filtrate containing only the fungal biomolecules, resulting in the formation of free nanoparticles in the dispersion. This last method is most widely used, since no procedures are required to release the nanoparticles from the cells (Azmath et al., 2016; Sabri et al., 2016; Costa Silva et al., 2017; Gudikandula et al., 2017). Nonetheless, the nanoparticle dispersion must be purified in order to eliminate fungal residues and impurities, which can be achieved using methods such as simple filtration, membrane filtration, gel filtration, dialysis, and ultracentrifugation (Ashrafi et al., 2013; Qidwai et al., 2018; Yahyaei and Pourali, 2019).

\section{SYNTHESIS MECHANISMS}

\section{How Does Extracellular Synthesis of Silver Nanoparticles by Fungi Occur?}

Although many studies have been published concerning the biogenic synthesis of silver nanoparticles using fungi, the specific mechanisms involved have not yet been fully elucidated. It is known that extracellular synthesis of nanoparticles occurs according to reactions in which the enzymes present in the fungal filtrate act to reduce silver ions, producing elemental silver 
$\left(\mathrm{Ag}^{0}\right)$ at a nanometric scale. After the reaction, the color of the filtrate changes and UV-visible spectroscopy can be used to observe surface plasmon resonance bands reflecting alteration of the optical properties of the material (Ahmad et al., 2003). The absorbance wavelengths of these bands vary in the range from 400 to $450 \mathrm{~nm}$, with an absorbance peak at a longer wavelength indicating the presence of larger nanoparticles (Elamawi et al., 2018). The size depends on the synthesis conditions such as fungus species, temperature, $\mathrm{pH}$, and dispersion medium, as well as the presence of cappings on the nanoparticles (Khandel and Shahi, 2018; Lee and Jun, 2019). The color of the dispersion is also directly related to the surface plasmon resonance, which varies according to the size and absorbance of the nanoparticles (Adeeyo and Odiyo, 2018; Bhangale et al., 2019; Lee and Jun, 2019).

Many biomolecules can react with silver ions and act in the synthesis, such as those associated with the complex pathways involving electron transfer during the conversion of NADPH/NADH to $\mathrm{NADP}^{+} / \mathrm{NAD}^{+}$(Thakkar et al., 2010; Gudikandula et al., 2017). Nicotinamide adenine dinucleotide $(\mathrm{NADH})$ and $\mathrm{NADH}$-dependent nitrate reductase enzymes are considered to be most important in the biogenic synthesis of metallic nanoparticles (Zomorodian et al., 2016; Baymiller et al., 2017; Figure 1).

In recent work, Hietzschold et al. (2019) showed that nanoparticle synthesis occurred by the action of NADPH, without any need for the nitrate reductase enzyme. This is particularly interesting, since it leads to the possibility of using different organisms for the synthesis of nanoparticles, without the necessary condition of reductase enzyme production. However, Durán et al. (2005) synthesized silver nanoparticles using Fusarium oxysporum and suggested that the reduction of silver ions was due to the action of the nitrate reductase enzyme and anthraquinones. In another study, using purified nitrate reductase and phytochelatins from the same fungus, it was found that extracellular NADPH-dependent nitrate reductase enzymes and quinones were responsible for the formation of nanoparticles (Kumar et al., 2007).

\section{Optimization of Silver Nanoparticles Synthesis}

Although the synthesis of silver nanoparticles using fungi is simple and effective, the parameters employed in the procedure must be optimized in order to achieve good monodispersity, stability, and biocompatibility of the particles (Balakumaran et al., 2015). Given that a wide variety of fungi have potential for use in the synthesis, it is important to consider their individual characteristics and to optimize the synthesis conditions accordingly (Ottoni et al., 2017).

Parameters such as agitation, temperature, light, and culture and synthesis times differ depending on the fungus used and can also be adjusted in order to obtain the desired nanoparticle characteristics. Control of nanoparticle size and shape requires adjustment of the parameters used for both cultivation of the fungus and the synthesis process (Birla et al., 2013). Studies have found that changes in temperature, concentration of the metal precursor, $\mathrm{pH}$, culture medium, and amount of biomass can be used to obtain nanoparticles with different physicochemical characteristics (Birla et al., 2013; Rajput et al., 2016; Saxena et al., 2016; Liang et al., 2017). Table 1 shows some studies in which silver nanoparticles were produced using different fungal species and synthesis conditions.

\section{Effect of Temperature}

The temperature used in the synthesis of silver nanoparticles employing fungi can affect parameters such as the speed of the synthesis and the size and stability of the nanoparticles (Elamawi et al., 2018).

In synthesis performed using the filtrate of Trichoderma harzianum, Ahluwalia et al. (2014) observed that the synthesis rate increased as the temperature was increased up to $40^{\circ} \mathrm{C}$, which was considered the ideal temperature. In other work using the filtrate of Fusarium oxysporum, higher protein secretion by the fungal biomass was observed at temperatures between 60 and $80^{\circ} \mathrm{C}$, with progressive increases of the synthesis rate and surface plasmon absorbance as the temperature increased (Birla et al., 2013). In synthesis using the endophytic fungus Colleotrichum sp. ALF2-6, Azmath et al. (2016) found that the reaction rate increased at higher temperatures, with the synthesis being completed within $20 \mathrm{~min}$ at temperatures above $50^{\circ} \mathrm{C}$. In the work by Phanjom and Ahmed (2017), using Aspergillus oryzae (MTCC no. 1846), a higher temperature also increased the rate of synthesis, with temperatures of $30,50,70$, and $90^{\circ} \mathrm{C}$ resulting in the synthesis being concluded in $6 \mathrm{~h}, 1 \mathrm{~h}$, $45 \mathrm{~min}$, and $20 \mathrm{~min}$, respectively, while no synthesis occurred at $10^{\circ} \mathrm{C}$. In the work of AbdelRahim et al. (2017), no synthesis of silver nanoparticles was observed using the filtrate of Rhizopus stolonifer at 80 or $10^{\circ} \mathrm{C}$, which was attributed to denaturation or inactivation of enzymes and other molecules.

Although most studies have reported faster rates of synthesis at higher temperatures, it is important to take into account the quality of nanoparticles. In addition to influencing the synthesis rate, the temperature can affect nanoparticle size and stability. In the work of AbdelRahim et al. (2017), nanoparticles were obtained with sizes of $2.86,25.89$, and $48.43 \mathrm{~nm}$, at temperatures of 40,20 , and $60^{\circ} \mathrm{C}$, respectively, with the smallest size observed at the intermediate temperature. Shahzad et al. (2019) synthesized nanoparticles using the fungus Aspergillus fumigatus BTCB10, obtaining a size of $322.8 \mathrm{~nm}$ at $25^{\circ} \mathrm{C}$ and increasing size as the temperature was increased, reaching $1073.45 \mathrm{~nm}$ at $55^{\circ} \mathrm{C}$. The size increase was attributed to the aggregation of nanoparticles at higher temperature. Elsewhere, Husseiny et al. (2015) used the fungus Fusarium oxysporum and found that the nanoparticle size decreased as the temperature was increased to $50^{\circ} \mathrm{C}$, with the smallest size $(30.24 \mathrm{~nm})$ at this temperature. In the work by Fayaz et al. (2009), using the fungus Trichoderma viride, the nanoparticle size was also found to decrease as the synthesis temperature increased.

These different results indicate that the effect of temperature on the size and stability of the nanoparticles synthesized varies according to the fungus species used. Banu and Balasubramanian (2014a) reported that $30^{\circ} \mathrm{C}$ was the optimum temperature for production of high stability silver nanoparticles using Isaria 


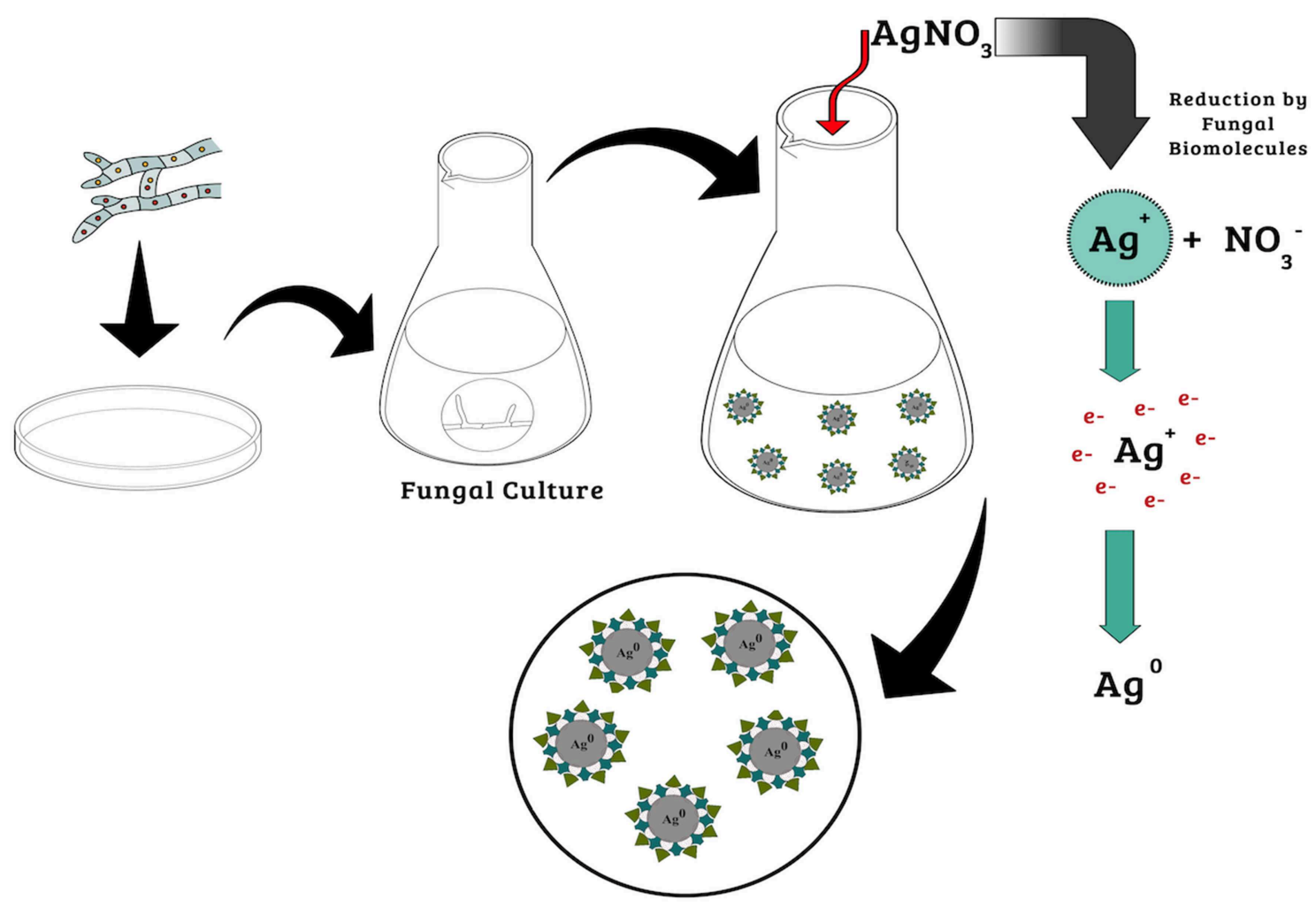

FIGURE 1 | Mechanisms of biogenic synthesis of silver nanoparticles.

fumosorosea. Balakumaran et al. (2015) also found that this was the optimum temperature for synthesis of nanoparticles using the fungus Guignardia mangifera. In the work of Costa Silva et al. (2017), using Duddingtonia flagans, the optimum synthesis temperature was $60{ }^{\circ} \mathrm{C}$. These differences in the effect of the synthesis temperature occur even within the same fungal genus. Trichoderma longibrachiatum presented a specific synthesis temperature of $28^{\circ} \mathrm{C}$, with no production of nanoparticles at 23 or $33^{\circ} \mathrm{C}$ (Elamawi et al., 2018), while Trichoderma viride presented viable synthesis at temperatures of 10,27 , and $40^{\circ} \mathrm{C}$ (Fayaz et al., 2009).

The occurrence of synthesis of nanoparticles by some fungal species at high temperatures indicates that electrons can be transferred from free amino acids to silver ions. However, very high temperatures, between 80 and $100^{\circ} \mathrm{C}$, lead to denaturation of the proteins that compose the nanoparticle capping. This denaturation alters the nucleation of $\mathrm{Ag}^{+}$ions, with the nanoparticles aggregating and increasing in size (Birla et al., 2013). According to Husseiny et al. (2015), unsuitable temperatures lead to increased nanoparticle size and loss of stability, due to the low activity of the enzymes involved in the synthesis.

\section{Effect of $\mathrm{pH}$}

Adjustment of the synthesis $\mathrm{pH}$ can be used to control certain characteristics of the nanoparticles. Nayak et al. (2011) reported that the conformation of nitrate reductase enzymes could be altered according to the concentration of protons in the reaction medium, leading to alteration of the morphology and size of the nanoparticles. At higher $\mathrm{pH}$, there is greater competition between protons and metal ions for establishing bonds with negatively charged regions, resulting in greater success of synthesis at alkaline pH (Sintubin et al., 2009).

Qian et al. (2013) observed that alkaline $\mathrm{pH}$ favored the synthesis of silver nanoparticles when $\mathrm{AgNO}_{3}$ was added to the filtrate of the fungus Epicoccum nigrum. Du et al. (2015) found that a more alkaline $\mathrm{pH}$ resulted in a shorter synthesis time and smaller nanoparticle size distribution and polydispersity index values. These characteristics indicate improved stability, due to the electrostatic repulsion of anions present in the dispersion (Gurunathan et al., 2009). Synthesis employing Colleotrichum sp. ALF2-6 at alkaline $\mathrm{pH}$ and a higher temperature of $50^{\circ} \mathrm{C}$ was faster than at lower $\mathrm{pH}$ and was completed in around $20 \mathrm{~min}$ (Azmath et al., 2016). In the synthesis performed by Birla et al. (2013), using Fusarium oxysporum, maximum nanoparticle production occurred between $\mathrm{pH} 9$ and 11, with lower production at $\mathrm{pH} 7$ and formation of aggregates between pH 3 and 5. However, Husseiny et al. (2015), using the same fungus, found that the nanoparticle synthesis rate decreased as the $\mathrm{pH}$ was increased, which was suggested to be due to lower activity of the reductases responsible for the synthesis at higher $\mathrm{pH}$.

Some studies have reported successful syntheses at neutral or slightly alkaline $\mathrm{pH}$. Nanoparticles synthesized using 
TABLE 1 | Optimization of the synthesis of silver nanoparticles by fungi.

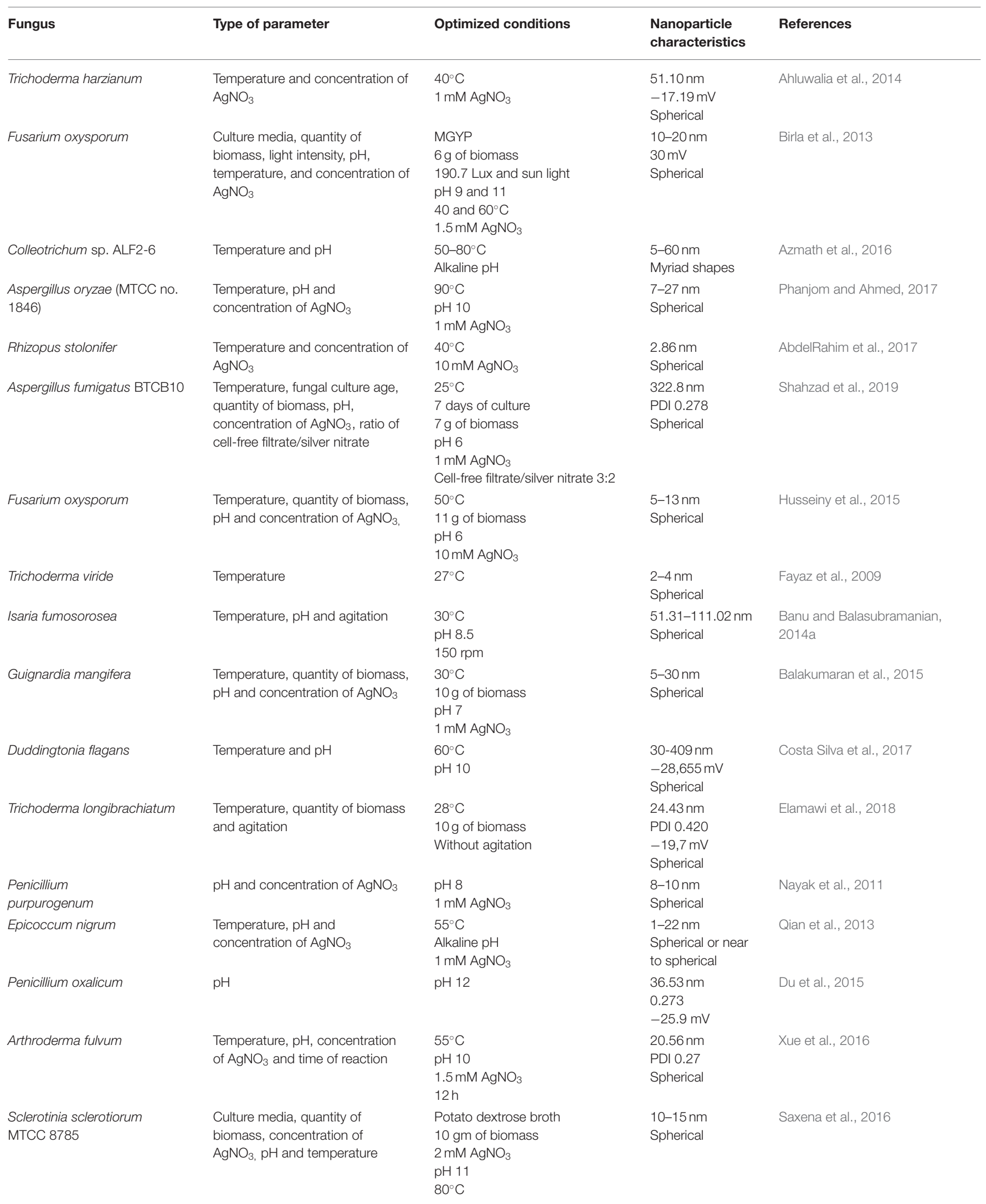


TABLE 1 | Continued

\begin{tabular}{|c|c|c|c|c|}
\hline Fungus & Type of parameter & Optimized conditions & $\begin{array}{l}\text { Nanoparticle } \\
\text { characteristics }\end{array}$ & References \\
\hline Fusarium oxysporum & $\begin{array}{l}\text { Concentration of } \mathrm{AgNO}_{3} \text { and } \\
\text { quantity of biomass }\end{array}$ & $\begin{array}{l}5 \mathrm{mM} \mathrm{AgNO}_{3} \\
4.96 \mathrm{~g} / \mathrm{L} \text { of biomass }\end{array}$ & $\begin{array}{l}25-50 \mathrm{~nm} \\
\text { Almost spherical }\end{array}$ & Korbekandi et al., 2013 \\
\hline Fusarium oxysporum & Temperature culture media & $\begin{array}{l}28^{\circ} \mathrm{C} \\
\text { Modified medium for } \\
\text { nitrate reductase }\end{array}$ & $\begin{array}{l}24 \mathrm{~nm} \\
\text { PDI } 0.23 \\
\text { Spherical }\end{array}$ & Hamedi et al., 2017 \\
\hline Penicillium oxalicum GRS-1 & $\begin{array}{l}\text { Temperature, quantity of } \\
\text { biomassa, concentration of } \\
\mathrm{AgNO}_{3} \text { and } \mathrm{pH}\end{array}$ & $\begin{array}{l}60^{\circ} \mathrm{C} \\
25 \mathrm{~g} \text { of biomass } \\
1.5 \mathrm{mM} \mathrm{AgNO}_{3} \\
\mathrm{pH} 7\end{array}$ & $\begin{array}{l}10-40 \mathrm{~nm} \\
\text { Spherical }\end{array}$ & Rose et al., 2019 \\
\hline
\end{tabular}

Isaria fumosorosea at $\mathrm{pH} 8.5$ showed better physicochemical characteristics, compared to nanoparticles synthesized at $\mathrm{pH} 4.5$ and 6.5 (Banu and Balasubramanian, 2014a). In synthesis using Guignardia mangiferae, no color change was observed between pH 1 and 4, while coloration started to appear at pH 5 and 6. As the $\mathrm{pH}$ was increased, the intensity of the dispersion increased, with the nanoparticles presenting greater monodispersion and stability at pH 7 (Balakumaran et al., 2015).

\section{Effect of $\mathrm{AgNO}_{3}$ Concentration}

In most of the studies employing fungi for extracellular synthesis of silver nanoparticles, $\mathrm{AgNO}_{3}$ was used at a concentration of $1 \mathrm{mM}$ (Saxena et al., 2016; Xue et al., 2016). In some cases, a lower metal precursor concentration resulted in a smaller nanoparticle size and an improved dispersion (Kaviya et al., 2011; Phanjom and Ahmed, 2017). However, other studies obtained smaller sizes when intermediate $\mathrm{AgNO}_{3}$ concentrations were used. AbdelRahim et al. (2017), employing the fungus Rhizopus stolonifer, obtained the smallest nanoparticle size $(2.86 \mathrm{~nm})$ at $10 \mathrm{mM} \mathrm{AgNO}$, while sizes of 54.67 and $14.23 \mathrm{~nm}$ were obtained at 100 and $1 \mathrm{mM}$, respectively. Similar results were reported by Husseiny et al. (2015), using Fusarium oxysporum.

Phanjom and Ahmed (2017) studied the synthesis of nanoparticles using Aspergillus oryzae and different $\mathrm{AgNO}_{3}$ concentrations between 1 and $10 \mathrm{mM}$. It was observed that at $\mathrm{AgNO}_{3}$ concentrations up to $8 \mathrm{mM}$, the nanoparticles presented sizes between 7.22 and $17.06 \mathrm{~nm}$, while the size increased to 45.93 and $62.12 \mathrm{~nm}$ at $\mathrm{AgNO}_{3}$ concentrations of 9 and $10 \mathrm{mM}$, respectively. This effect was attributed to the lack of functional groups available for the reaction when the metal precursor concentration was increased.

In addition to the effect on nanoparticle size, the $\mathrm{AgNO}_{3}$ concentration is related to the quantity of nanoparticles produced. In a study employing Fusarium oxysporum, it was found that the quantity of nanoparticles increased as the precursor concentration was increased between 0.1 and $1.5 \mathrm{mM}$, while no differences were observed at higher concentrations (Birla et al., 2013). Similar results were reported elsewhere for syntheses employing Penicillium purpurogenum (Nayak et al., 2011) and Fusarium oxysporum (Korbekandi et al., 2013).
These findings suggest that there is a limit to the concentration of $\mathrm{AgNO}_{3}$ used, in order to obtain nanoparticles with satisfactory physicochemical characteristics. The addition of excess amounts of metal ions results in very large nanoparticles with irregular morphology (AbdelRahim et al., 2017), due to competition between the silver ions and functional groups from the fungus filtrate (Shahzad et al., 2019). As the concentration of the metal precursor increases, so also does the intensity of color of the dispersion (Ahluwalia et al., 2014; Phanjom and Ahmed, 2017). In addition, a higher concentration of $\mathrm{AgNO}_{3}$ may lead to greater toxicity (Balakumaran et al., 2015).

\section{Effect of the Culture Medium}

It is known that microorganisms present different responses, depending on the culture medium and the cultivation conditions. Changes in these conditions result in the synthesis of different metabolites and proteins (Costa Silva et al., 2017).

In nanoparticle synthesis using fungi, a culture medium containing substrate specific for the enzymes that act in the synthesis can induce their production and release by the fungus, enhancing the reduction of silver and the formation of nanoparticles (Husseiny et al., 2015). In the work by Hamedi et al. (2017), Fusarium oxysporum was cultivated in a culture medium modified to induce nitrate reductase enzyme activity $(0.35 \%$ yeast extract, $1 \%$ peptone, $0.35 \%$ potassium nitrate, and $1.5 \%$ glucose), as well as in malt glucose yeast peptone (MGYP) medium without enzyme induction ( $0.3 \%$ malt extract, $1 \%$ glucose, $0.3 \%$ yeast extract, and $0.5 \%$ peptone). The nanoparticle dispersions produced using the filtrate from the fungus cultivated in the enzyme induction medium presented higher concentrations and smaller sizes of the nanoparticles, which was attributed to stimulation of the enzymatic activity by the nitrogen source in the modified medium, hence increasing nanoparticle production.

Different behaviors were observed in studies in which different media were tested for the cultivation of fungi. Saxena et al. (2016) synthesized silver nanoparticles using Sclerotinia sclerotiorum cultivated in various broths, with the highest nanoparticle production achieved using potato dextrose medium. In work by Costa Silva et al. (2017), using the fungus Duddingyonia flagans for the synthesis of silver nanoparticles, the biomass was transferred to pure water and to water containing 
insect carapaces as a natural source of chitin (a substrate for fungal enzymes). The filtrate supplemented with chitin contained around three times more protein and presented higher nanoparticle production.

Birla et al. (2013) tested 10 different media for cultivation of Fusarium oxysporum, obtaining higher production of silver nanoparticles using the filtrate from the fungus cultivated in MGYP medium. Conversely, Ashrafi et al. (2013) found that the same medium inhibited the production of silver nanoparticles using the filtrate from Rhizoctonia solani, while the synthesis was successful when potato dextrose medium was used to cultivate the fungus. It was suggested that the activity of the enzyme responsible for the reduction process could have been inhibited by a component of the medium.

\section{Effect of the Quantity of Biomass}

The amount of biomass used can affect the synthesis and characteristics of silver nanoparticles. Some studies have reported higher nanoparticle production using lower biomass concentrations, while others have found higher synthesis rates using higher concentrations (Birla et al., 2013; Korbekandi et al., 2013; Balakumaran et al., 2015; Elamawi et al., 2018).

Balakumaran et al. (2015) used the filtrate obtained from 10,20 , and $30 \mathrm{~g}$ quantities of Guignardia mangiferae biomass in $100 \mathrm{~mL}$ of water, obtaining silver nanoparticles with better physicochemical characteristics when the lowest biomass concentration was used. Shahzad et al. (2019) evaluated the use of $1,4,7$, and $10 \mathrm{~g}$ quantities of Aspergillus fumigatus BTCB10 biomass, observing greater production, smaller size, and better dispersion of the nanoparticles when the synthesis was based on the use of $7 \mathrm{~g}$ of biomass. In the work of Rose et al. (2019), employing Penicillium oxalicum, greater nanoparticle production was obtained using a higher biomass concentration, which was attributed to greater release of the nitrate reductase enzyme by the mycelium. Saxena et al. (2016) observed higher silver nanoparticle production when the amount of Sclerotinia sclerotiorum biomass was increased. Birla et al. (2013) reported the existence of a relationship between the amount of biomass and the release of biomolecules responsible for the synthesis.

Despite the differences in the amount of biomass used, depending on the fungus species employed, it can be concluded that successful synthesis of nanoparticles necessitates a suitable balance between the amount of organic material, derived from the fungus, and the amount of metal precursor (Phanjom and Ahmed, 2017; Shahzad et al., 2019).

In summary, it is clear that different synthesis conditions can result in different characteristics of the nanoparticles, as well as success or failure of the synthesis. However, the effects of the different parameters remain unclear, requiring further detailed studies for each organism used. It is also important to define the desired physicochemical characteristics of the nanoparticles, in order to establish the parameters used in the synthesis, such as temperature, $\mathrm{pH}$, and time, among others. The optimization of synthesis techniques should enable the achievement of fast large-scale nanoparticle production. This opens avenues for the use of these nanomaterials to solve problems such as bacterial resistance to antibiotics and phytopathogens that affect agricultural production.

\section{Importance of Capping and Stabilization of the Nanoparticles}

The synthesis of nanoparticles by non-biogenic methods requires an additional step in which polymers and surfactants are used to coat their surfaces. This process, known as functionalization, employs biomolecules that facilitate the anchoring of desired substances on the nanoparticle surfaces (Mout et al., 2012). In the case of biogenic synthesis, formation of the capping occurs simultaneously with formation of the nanoparticles, employing biomolecules derived from the organism used in the synthesis, so no additional steps are required (Chowdhury et al., 2014).

Biomolecules derived from the reducing organism have high capacities for binding to metals, with proteins and amino acid residues binding to the nanoparticle surfaces to form cappings that confer stability and prevent particle agglomeration and aggregation (Basavaraja et al., 2008; Gopinath et al., 2012). The binding of proteins at the surfaces, with consequent stabilization, may involve free amino groups or cysteine residues. Stabilization can also be provided by mycelial cell wall enzymes present in the filtrate, whose negative carboxyl groups provide electrostatic attraction (Gole et al., 2001; Husseiny et al., 2015). According to Gurunathan et al. (2009), the stability of silver nanoparticles is also provided by nucleophilic $\mathrm{OH}^{-}$ions that are adsorbed on the surfaces, preventing aggregation and contributing to the synthesis of smaller nanoparticles by providing electrons for the reduction of silver ions.

In addition to conferring stability to the nanoparticles, the protein capping resulting from biogenic synthesis can act in the anchoring of drugs and genetic material for subsequent transport into cells (Hu et al., 2011; Zhang et al., 2016). The non-toxic organic composition of the capping means that it biocompatible, which can increase the rate of internalization and retention of nanoparticles (Rodrigues et al., 2013; Mohanta et al., 2018; Figure 2).

Despite their importance, there have been few studies of the cappings on biogenic nanoparticles. Gade et al. (2008) detected sulfur atoms in samples of silver nanoparticles synthesized using Aspergillus niger, indicative of the presence of proteins enveloping the nanoparticles. Chowdhury et al. (2014) used scanning electron microscopy to detect the presence of cappings on biogenic silver nanoparticles. The nanoparticles were spherical, polydispersed, and were not in direct contact, even within aggregates, indicating good stability. The SDS-Page protein electrophoresis technique was employed to characterize the extracellular fungal proteins associated with the nanoparticles. Molecular weight bands between 50 and $116 \mathrm{kDa}$ were attributed to proteins responsible for synthesis and stabilization of the nanoparticles. Both the filtrate and the capping removed from nanoparticles showed a band at 85 $\mathrm{kDa}$, which corresponded to a protein that was suggested to be responsible for the stability of the nanoparticles.

Elgorban et al. (2016) synthesized biogenic silver nanoparticles and confirmed the presence of a capping 


\section{CAPPFD AEINPS}

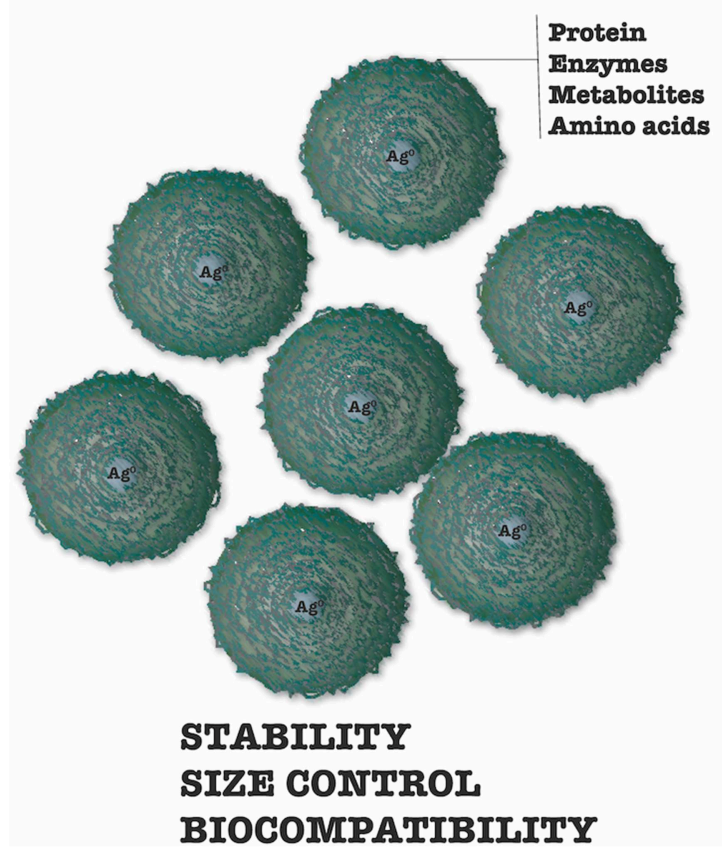

\section{UNCAPPED AgNPS}
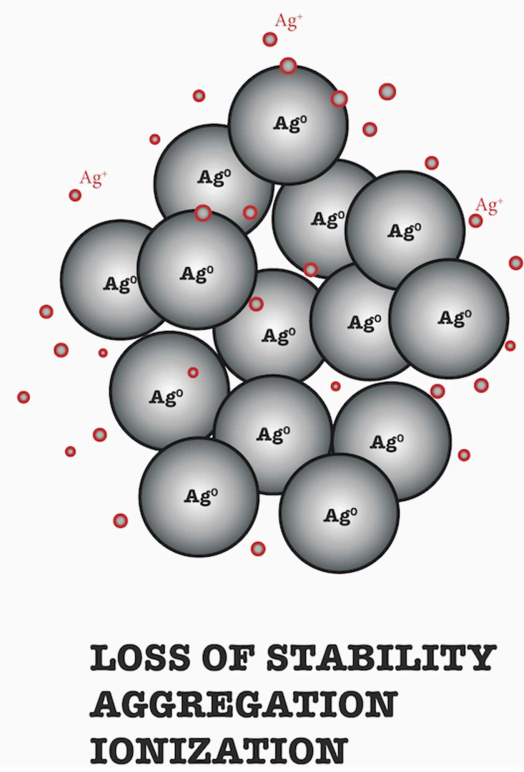

FIGURE 2 | Differences between capped and uncapped silver nanoparticles.

by microscopic analyses. The use of transmission electron microscopy revealed a thin layer of organic material surrounding the particles. Signals corresponding to oxygen and carbon were observed using scanning electron microscopy, indicating the presence of organic compounds derived from the filtrate, which were adsorbed on the nanoparticle surfaces.

Devi and Joshi (2015) synthesized silver nanoparticles using the endophytic fungi Aspergillus tamarii, Aspergillus niger, and Penicillium ochrochloron. UV-Vis absorption analysis revealed peaks at 419, 430, and $430 \mathrm{~nm}$, respectively. A peak at $280 \mathrm{~nm}$ was attributed to the presence in the filtrate of amino acid residues such as tryptophan and tyrosine, which were secreted by the fungi.

Given the importance of the cappings on biogenic nanoparticles, future studies are needed to investigate their compositions and biological activities. The use of synergy between nanometric silver and biomolecule cappings active against specific pathogens is likely to be a development in the near future.

\section{APPLICATIONS}

Silver nanoparticles synthesized using fungi have various potential applications in the areas of health, agriculture, and pest control. There are no reports concerning the better or worse activities of biogenic nanoparticles synthesized from different sources, such as fungi, bacteria, or plants. However, synthesis based on fungi may be advantageous in terms of production, due to the large quantities of metabolites produced. Another factor to consider is the capacity of fungi to produce antibiotics that could be contained in the capping and act in synergy with the nanoparticle core.

Many studies of biogenic synthesis of nanoparticles using fungi have shown results that are promising for the application of these systems in controlling pathogenic fungi and bacteria, combating cancer cells and viruses, and providing larvicidal and insecticidal activities (Figure 3).

\section{Health Applications}

Several studies have described the use of biogenic silver nanoparticles for applications in the area of health, involving the control of bacteria and fungi. Bacterial growth is directly inhibited by the nanoparticles, which contact the cell wall and cause progressive metabolic responses, with the production of reactive oxygen species (Gudikandula et al., 2017).

The size of nanoparticles is one of the factors determining their antimicrobial potential, since smaller nanoparticles have greater effects ( $\mathrm{Lu}$ et al., 2013). Small nanoparticles can penetrate the bacterial cell membrane and damage the respiratory chain, alter permeability, cause DNA and RNA damage, affect cell division, and lead to cell death (Morones et al., 2005; Rai et al., 2009). Nanoparticles also interact with the thiol groups of essential enzymes, releasing $\mathrm{Ag}^{+}$ions that form complexes with nucleotides, damaging the microorganism DNA and inhibiting 


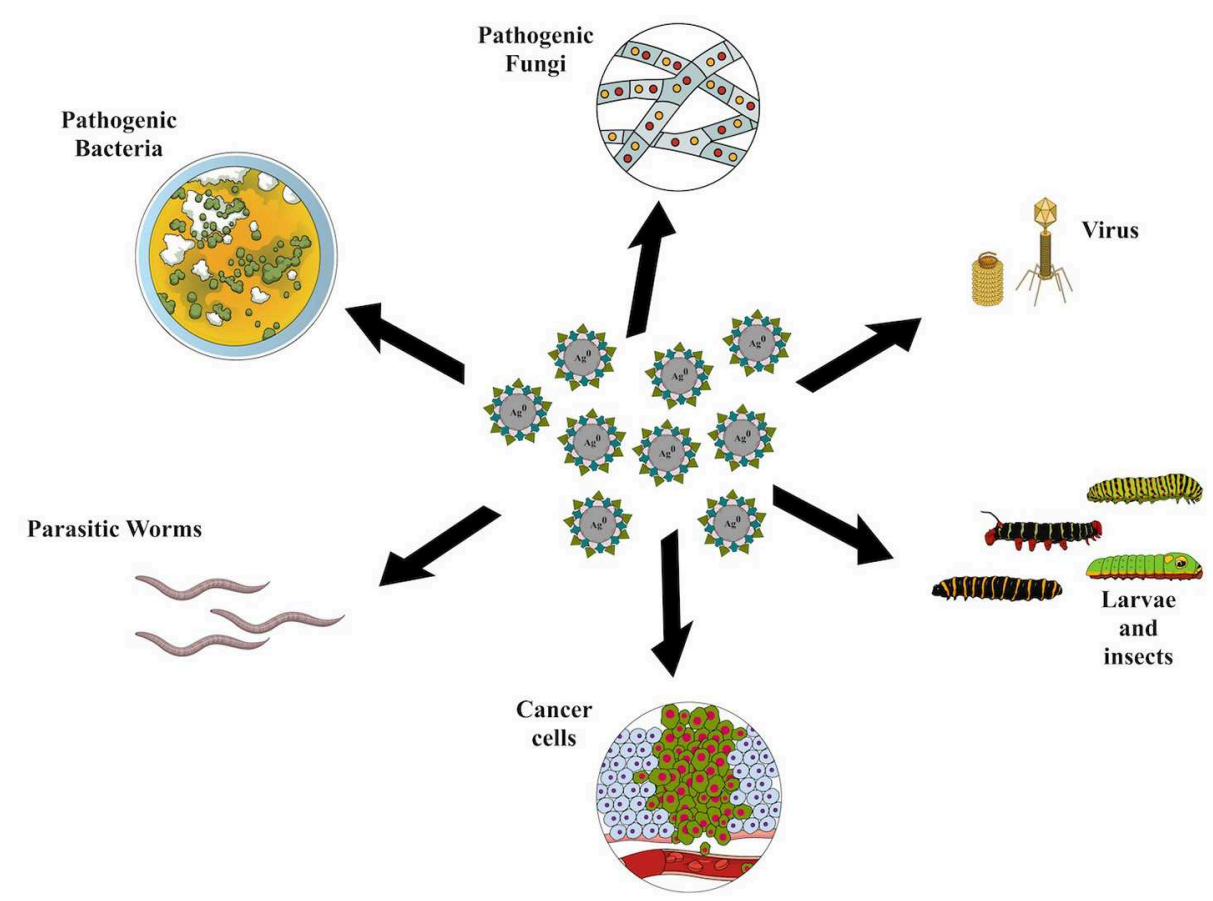

FIGURE 3 | Applications of silver nanoparticles synthesized using fungi.

the activity of DNases (Li et al., 2010; Baker and Satish, 2012).

Materials with antifungal potential (such as biogenic silver nanoparticles) that are obtained from sustainable sources can be inexpensive and safe options for the treatment of systemic and surface fungal infections, enabling the control of resistant fungi (Ashajyothi et al., 2016). The large surface area of silver nanoparticles and the release of ions can contribute to high antimicrobial activity. The toxic ions bind to proteins containing sulfur, affecting cell permeability and leading to alteration of the DNA replication process. The inactivation of some enzymes is also caused by the binding of nanoparticles with thiol groups. This inactivation leads to oxidative stress, which influences electron transport and protein oxidation (Reidy et al., 2013; Rai et al., 2014; Fátima et al., 2016).

Table 2 shows some studies in which silver nanoparticles synthesized from different fungal species were employed for health issues.

Ahluwalia et al. (2014) synthesized silver nanoparticles using Trichoderma harzianum, which were used to control the bacteria Staphylococcus aureus and Klebsiella pneumoniae in vitro. The inhibition rates were concentration-dependent, with the gram-negative bacterium (K. pneumoniae) showing higher sensitivity. Balakumaran et al. (2015) reported the potential of silver nanoparticles synthesized using the fungus Guignardia mangiferae for the control of gram-negative bacteria, with effects including increased permeability, alteration of membrane transport, and release of nucleic acids.
The lower effects of silver nanoparticles toward gram-positive bacteria may be because the peptidoglycans that compose the cell wall act as a barrier that prevents internalization of the nanoparticles (Shrivastava et al., 2007). However, in some studies, the nanoparticles exhibited inhibitory effects against this bacterial type. In evaluation of the antimicrobial activity of silver nanoparticles synthesized using Aspergillus niger, Gade et al. (2008) observed inhibitory effects against the bacteria $E$. coli and $S$. aureus that were equivalent to those of the antibiotic gentamicin, with the gram-positive bacterium ( $S$. aureus) showing higher sensitivity.

Silver nanoparticles have also been used in combination with antibiotics and antifungals, representing a possible solution to the problem of resistance toward these drugs used in the health area. Bhat et al. (2015) synthesized silver nanoparticles using Candida albicans and evaluated their effects when used alone or in combination with the antibiotic ciprofloxacin against Staphylococcus aureus, Escherichia coli, Bacillus cereus, Vibrio cholerae, and Proteus vulgaris. It was found that the activity of the antibiotic increased when it was used together with the nanoparticles, while the latter also showed antimicrobial potential when they were used alone.

Fátima et al. (2016) evaluated the antimicrobial and antifungal activities of silver nanoparticles synthesized using the filtrate from Aspergillus flavus. The nanoparticles were effective in controlling the bacteria Bacillus cereus, Bacillus subtilis, Enterobacter aerogenes, Escherichia coli, and Staphylococcus aureus, with $B$. subtilis and $E$. coli being most sensitive. The activity was concentration-dependent, with better results 
TABLE 2 | Health applications of silver nanoparticles synthesized by fungi.

\begin{tabular}{|c|c|c|c|c|}
\hline Synthesis source & Bioactivity & Target organism & Effective concentration & References \\
\hline Macrophomina phaseolina & Antibacterial & Multidrug resistant strains of Escherichia coli & $\begin{array}{l}0.51 ; 0.36 ; 0.25 ; 0.10 \text {; and } 0.05 \mu \mathrm{g} / \mathrm{mL} \\
\text { (concentration-dependent) }\end{array}$ & Chowdhury et al., 2014 \\
\hline $\begin{array}{l}\text { Rhizopus arrhizus IPT1011; } \\
\text { Rhizopus arrhizus IPT1013; } \\
\text { Trichoderma gamsii IPT853; } \\
\text { Aspergillus niger IPT856 }\end{array}$ & Antibacterial & E. coli, Staphylococcus aureus, and P. aeruginosa & $1.0 ; 5.0 ; 10 ; 50 ;$ and $100 \mu \mathrm{g} / \mathrm{mL}$ & Ottoni et al., 2017 \\
\hline Fusarium verticillioides & Antibacterial & S. aureus and E. coli & 5 and $10 \mathrm{mM}$ & Mekkawy et al., 2017 \\
\hline Alternaria sp. & Antibacterial & $\begin{array}{l}\text { Bacillus subtilis, S. aureus, E. Coli, and Serratia } \\
\text { marcescens }\end{array}$ & $\begin{array}{l}5,10,15,20 \text {, and } 25 \mathrm{mg} / \mathrm{mL} \\
\text { (concentration-dependent) }\end{array}$ & Singh et al., 2017 \\
\hline Penicillium aculeatum Su1 & Antibacterial & $\begin{array}{l}\text { E. coli, P. aeruginosa, S. aureus, B. Subtilis, and } \\
\text { Candida albicans }\end{array}$ & $\begin{array}{l}\text { 50, } 100 \text {, and } 200 \mu \mathrm{g} / \mathrm{mL} \\
\text { (concentration-dependent) }\end{array}$ & Liang et al., 2017 \\
\hline Pleurotus djamor var. roseus & $\begin{array}{l}\text { Antiproliferative } \\
\text { in cancer cells }\end{array}$ & PC3 cells (prostate cancer) & $10-40 \mu \mathrm{g} / \mathrm{mL}$ & Raman et al., 2015 \\
\hline $\begin{array}{l}\text { Sclerotinia sclerotiorum } \\
\text { MTCC8785 }\end{array}$ & Antibacterial & E. coli and S. aureus & 100,200 , and $400 \mathrm{ppm}$ & Saxena et al., 2016 \\
\hline Colletotrichum sp. ALF2-6 & Antibacterial & E. coli, Salmonella typhi, B. Subtilis, and S. aureus & $\begin{array}{l}50 \mu \mathrm{g} / \mathrm{mL} \text { (S. aureus) and } 100 \mu \mathrm{g} / \mathrm{mL} \\
\text { (others) }\end{array}$ & Azmath et al., 2016 \\
\hline $\begin{array}{l}\text { Penicillium chrysogenum and } \\
\text { Aspergillus oryzae }\end{array}$ & Antifungal & Trichophyton rubrum & $\begin{array}{l}\text { P. chrysogenum } 0.5 \mu \mathrm{g} / \mathrm{mL} \text { and A. oryzae } \\
>7.5 \mu \mathrm{g} / \mathrm{mL}\end{array}$ & Pereira et al., 2014 \\
\hline Schizophyllum radiatum & Antibacterial & B. subtilis and Salmonella paratyphi & $60 \mu \mathrm{L} /$ well & Metuku et al., 2014 \\
\hline $\begin{array}{l}\text { Trichophyton rubrum, } T \text {. } \\
\text { mentagrophytes and } \\
\text { Microsporum canis }\end{array}$ & Antifungal & C. albicans & $4 \mu \mathrm{g} / \mathrm{mL}$ & Moazeni et al., 2012 \\
\hline Penicillium italicum & $\begin{array}{l}\text { Antibacterial } \\
\text { and antifungal }\end{array}$ & $\begin{array}{l}\text { Multidrug-resistant } S \text {. aureus, Shewanella } \\
\text { putrefaciens, and C. albicans }\end{array}$ & $25 \mu \mathrm{L} / \mathrm{disk}$ & Nayak et al., 2018 \\
\hline Arthroderma fulvum & Antifungal & Candida sp. and Aspergillus sp. & $0.125-4.00 \mu \mathrm{g} / \mathrm{mL}$ & Xue et al., 2016 \\
\hline Aspergillus versicolor & Antibacterial & $\begin{array}{l}\text { S. aureus, Streptococcus pneumonia, } P \text {. } \\
\text { Aeruginosa, and } K \text {. pneumoniae }\end{array}$ & $1 \mathrm{mg} / \mathrm{mL}$ & Netala et al., 2016 \\
\hline Aspergillus terreus & Antibacterial & Salmonella typhi, S. Aureus, and E. coli & $\begin{array}{l}11.43 \mu \mathrm{g} / \mathrm{mL} \\
-308 \mu \mathrm{g} / \mathrm{mL}\end{array}$ & Rani et al., 2017 \\
\hline Fusarium oxysporum & Antifungal & Candida spp. and Cryptococcus spp. & $\begin{array}{l}\text { Candida spp. } 0.84-1.68 \mu \mathrm{g} / \mathrm{mL} \text { and } \\
\text { Cryptococcus spp. } 0.42-0.84 \mu \mathrm{g} / \mathrm{mL}\end{array}$ & Ishida et al., 2014 \\
\hline
\end{tabular}

achieved using the nanoparticles in combination with the antibiotic tetracycline, rather than on their own. Concentrationdependent activity of the nanoparticles was also observed against the fungi Aspergillus niger and Trichoderma harzianum.

Gudikandula et al. (2017) used silver nanoparticles synthesized from the fungi Trametes ljubarsky and Ganoderma enigmaticum for the control of gram-positive and gram-negative bacteria (Bacillus subtilis, Staphylococcus aureus, Micrococcus luteus, Bacillus cereus, Bacillus megaterium, Escherichia coli, Enterobacter aerogens, Klebsiella pneumoniae, Salmonella typhimurium, Proteus vulgaris, Pseudomonas aeruginosa, and Salmonella paratyphi). Both types of nanoparticle were effective in controlling all the bacteria.

Ibrahim and Hassan (2016) synthesized silver nanoparticles using Alternaria alternata, which were capped with butyl acrylate and applied on cotton to inhibit the proliferation 
of microorganisms. At all the concentrations tested, the nanoparticle-treated cotton presented high antimicrobial activity against E. coli and S. aureus, achieving 99.9\% inhibition. Biogenic silver nanoparticles can also be effective against resistant microorganisms. For example, Singh et al. (2014) used an optimized synthesis process employing Penicillium sp. to produce silver nanoparticles that showed potential for the control of multidrug-resistant E. coli and S. aureus.

In addition to their antimicrobial potential, biogenic silver nanoparticles can exert effects on tumor cells. Husseiny et al. (2015) evaluated the antibacterial and antitumor potential of silver nanoparticles synthesized using Fusarium oxysporum. The nanoparticles were effective in controlling E. coli and S. aureus, as well as a tumor cell line. A low IC50 value $(121.23 \mu \mathrm{g}$ $\mathrm{cm}^{3}$ ) for MCF-7 cells (human breast adenocarcinoma) was obtained following exposure of the cells to the nanoparticles, indicating high cytotoxicity and the potential for tumor control. The effect was attributed to the involvement of the silver nanoparticles in disruption of the mitochondrial respiratory chain, which led to the production of reactive oxygen species and hindered the synthesis of adenosine triphosphate (ATP), consequently damaging the nucleic acids (Husseiny et al., 2015).

Balakumaran et al. (2015) evaluated the cytotoxic potential of silver nanoparticles, synthesized using the fungus Guignardia mangiferae, against $\mathrm{HeLa}$ (human cervical carcinoma) and MCF7 tumor cells, as well as normal Vero cells (African monkey kidney). Higher cytotoxicity was observed against the tumor cells, which showed signs of apoptosis, with condensed nuclei, membrane damage, and the presence of apoptotic bodies.

El-Sonbaty (2013) evaluated silver nanoparticles synthesized using the fungus Agaricus bisporus for their antitumor potential in vitro against MCF-7 tumor cells and in vivo against Ehrlich carcinoma in mice. The nanoparticles presented concentrationdependent activity in reducing the viability of the breast carcinoma cells. In the case of Ehrlich carcinoma, there was a decrease of blood vessels and an increase of apoptotic cells, with these effects being intensified when the application of nanoparticles was combined with exposure to gamma radiation. The cytotoxic effects of silver nanoparticles occur due to the interactions of the silver atoms with the groups of intracellular proteins and with the nitrogenous bases and phosphate groups of DNA (Sriram et al., 2010). Although the application of nanoparticles for the control of cancer is of considerable interest and has shown promising results in several studies, this technique still requires further investigation and the use of clinical trials (Balakumaran et al., 2015).

Biogenic silver nanoparticles have also shown effects against viruses. Gaikwad et al. (2013) synthesized silver nanoparticles using the fungi Alternaria sp., Fusarium oxysporum, Curvularia sp., Chaetomium indicum, and Phoma sp., which showed potential for reducing the replication of HSV-1, HSV-2, and HPIV-3 in cell cultures. The nanoparticles produced using $F$. oxysporum, Curvularia sp., and C. indicum were the most effective and presented low cytotoxicity, while the other two types were not used, due to their cytotoxicity.

\section{Agriculture and Pest Control Applications}

There have been few studies to evaluate the potential of silver nanoparticles synthesized using biogenic methods for the control of phytopathogenic fungi in agriculture and pests. Table 3 shows some studies in which silver nanoparticles synthesized from different fungal species were employed in agriculture and pests control.

Elgorban et al. (2016) synthesized silver nanoparticles using the fungus Aspergillus versicolor and observed their effects against Sclerotinia sclerotiorum and Botrytis cinerea in strawberry plants. The nanoparticles showed concentration-dependent activity toward both pests, with the greatest effect against $B$. cinerea. Qian et al. (2013) synthesized silver nanoparticles using the fungus Epicoccum nigrum and observed their activity against isolates of the pathogenic fungi C. albicans, Fusarium solani, Sporothrix schenckii, Cryptococcus neoformans, Aspergillus flavus, and Aspergillus fumigatus. Balakumaran et al. (2015) synthesized silver nanoparticles using the fungus Guignardia mangiferae and reported their potential to control the phytopathogenic fungi Colletotrichum sp., Rhizoctonia solani, and Curvularia lunata. In other work, silver nanoparticles synthesized using the phytopathogenic fungus Fusarium solani isolated from wheat were shown to be effective for the treatment of wheat, barley, and maize seeds contaminated by different species of phytopathogenic fungi (Abd El-Aziz et al., 2015).

Several studies have investigated the combination of biogenic nanoparticles and conventional biocides. Gajbhiye et al. (2009) synthesized silver nanoparticles using the fungus Alternaria alternata and evaluated their potential, in combination with the antifungal compound fluconazole, against the phytopathogenic fungi Phoma glomerata, Phoma herbarum, and Fusarium semitectum, as well as the biological control agent Trichoderma sp. and the human pathogenic fungus Candida albicans. The combination of the nanoparticles and fluconazole was effective, with $C$. albicans showing the highest sensitivity after exposure, followed by Trichoderma sp. and P. glomerata. Potentiation of antifungal activity was not observed for $F$. semitectum or P. herbarum. Gherbawy et al. (2013) synthesized silver nanoparticles using Trichoderma harzianum and applied them in combination with triclabendazole for controlling the parasite Fasciola sp., which affects sheep and cattle. The nanoparticles combined with triclabendazole inhibited egg hatching by $90.6 \%$, while use of the drug alone caused $70.6 \%$ inhibition. It was suggested that use of the nanoparticles together with the drug could be a way to overcome the resistance that the parasite has developed toward the drug.

Other studies have investigated the use of biogenic nanoparticles to control insect vectors. Sundaravadivelan and Padmanabhan (2014) synthesized silver nanoparticles using the filtrate from Trichoderma harzianum and observed concentration-dependent mortality when they were tested against the larvae and pupae of the dengue vector mosquito Aedes aegypti. In other work by Banu and Balasubramanian (2014a), silver nanoparticles synthesized using the entomopathogenic fungus Isaria fumosorosea were tested for control of the mosquito species Culex quinquefasciatus and Aedes aegypti, when applied 
TABLE 3 | Applications of silver nanoparticles synthesized by fungi in agriculture and pests control.

\begin{tabular}{|c|c|c|c|c|}
\hline Synthesis source & Bioactivity & Target organism & Effective concentration & References \\
\hline Trichoderma harzianum & Antifungal & Sclerotinia sclerotiorum & $\begin{array}{l}0.15 \times 10^{12} \text { and } 0.31 \times \\
10^{12} \mathrm{NPs} / \mathrm{mL}\end{array}$ & Guilger et al., 2017 \\
\hline $\begin{array}{l}\text { Trichoderma harzianum } \\
\text { SYA.F4 }\end{array}$ & Antifungal & $\begin{array}{l}\text { Helminthosporium sp., Alternaria alternata, } \\
\text { Phytophthora arenaria, and Botrytis sp. }\end{array}$ & $100 \mu \mathrm{g} / \mathrm{mL}$ & El-Moslamy et al., 2017 \\
\hline Arthroderma fulvum & Antifungal & Fusarium sp. & $0.125-4.00 \mu \mathrm{g} / \mathrm{mL}$ & Xue et al., 2016 \\
\hline Epicoccum nigrum & Antifungal & $\begin{array}{l}\text { Fusarium solani, Sporothrix schenckii, } \\
\text { Cryptococcus neoformans, Aspergillus } \\
\text { flavus, and Aspergillus fumigatus }\end{array}$ & $0.125-1.00 \mu \mathrm{g} / \mathrm{mL}$ & Qian et al., 2013 \\
\hline Guignardia mangiferae & Antifungal & $\begin{array}{l}\text { Colletotrichum sp., Rhizoctonia solani, and } \\
\text { Curvularia lunata }\end{array}$ & $1 \mathrm{mg} / \mathrm{mL}$ & Balakumaran et al., 2015 \\
\hline Fusarium solani & Antifungal & $\begin{array}{l}\text { Several fungal species isolated from wheat, } \\
\text { barley and corn }\end{array}$ & 1,2 , and $4 \%$ & Abd El-Aziz et al., 2015 \\
\hline Trichoderma harzianum & $\begin{array}{l}\text { Antiparasitic } \\
\text { combined } \\
\text { with } \\
\text { Triclabendazol }\end{array}$ & Fasciola hepatica & $50 \mu \mathrm{g} / \mathrm{mL}$ & Gherbawy et al., 2013 \\
\hline Trichoderma harzianum & Insecticide & Aedes aegypti & $0.2-1.0 \%$ & Sundaravadivelan and Padmanabhan, 2014 \\
\hline Isaria fumosorosea & Insecticide & Culex quinquefasciatus and Aedes aegypti & $0.3-1.0 \mathrm{ppm}$ & Banu and Balasubramanian, 2014a \\
\hline Beauveria bassiana & Insecticide & Aedes aegypti & $0.06-1.0 \mathrm{ppm}$ & Banu and Balasubramanian, 2014b \\
\hline
\end{tabular}

between instars 1 and 4 . Potential concentration-dependent control was observed for both species, with the greatest effectiveness against Aedes aegypti, for which the mortality of 1 st instar larvae reached $100 \%$ within $24 \mathrm{~h}$. The 4 th instar larvae of both species showed lower susceptibility to the nanoparticles. Based on these results, these nanoparticles were considered as potential larvicides for mosquito control. The same authors synthesized silver nanoparticles using the mycelial extract of the entomopathogenic fungus Beauveria bassiana and obtained $100 \%$ mortality of the 1 st and 2 nd instar larvae of Aedes aegypti within $21 \mathrm{~h}$ of exposure to the nanoparticles. The authors concluded that use of the nanoparticles could be an environmentally safe strategy for vector control, following scale-up of production and field applications (Banu and Balasubramanian, 2014b).

\section{CONCLUSION}

Recent studies show that the biogenic synthesis of silver nanoparticles using fungi offers several advantages and that these materials have promising potential for a range of applications in the areas of health and agriculture. The nanoparticles possess cappings derived from the fungi, which confer stability. Depending on the fungus used, this capping may also exhibit biological activity, acting in synergy with the effect of the nanoparticle core. The ability to use different species of fungi and to perform the synthesis under different conditions of temperature, $\mathrm{pH}$, quantity of biomass, and concentration of the metal precursor, among others, enables the production of nanoparticles that have different physicochemical characteristics.
However, in order to successfully use fungi for biogenic synthesis, there are a number of disadvantages that must be overcome. These include the need to know which fungus to use, its growth parameters, the need for sterile conditions, and the time required for fungal growth and for the synthesis to be completed. There can also be difficulties associated with scale-up, including the need for further investigation concerning the mechanisms of formation of capping layers and the molecules present in them.

Although progress is required on some issues, the studies published to date show that the use of fungi for biogenic synthesis of silver nanoparticles can lead to a wide range of possible applications. These nanoparticles offer considerable potential for exploitation in the control of pathogenic microorganisms.

\section{AUTHOR CONTRIBUTIONS}

MG-C and RL wrote the manuscript and prepared the figures. All authors read and approved the final manuscript.

\section{FUNDING}

This work was supported by the University of Sorocaba/UNISO and São Paulo Research Foundation (FAPESP) (Grant \#2016/13692-6 and \#2017/13328-5).

\section{ACKNOWLEDGMENTS}

The authors are grateful to University of Sorocaba/UNISO for supporting the publication charges. 


\section{REFERENCES}

Abd El-Aziz, A. R. M., Al-Othman, M. R., Mahmoud, M. A., and Metwaly, H. A. (2015). Biosynthesis of silver nanoparticles using Fusarium solani and its impact on grain borne fungi. Dig. J. Nanomater Bios. 10, 655-662.

AbdelRahim, K., Mahmoud, S. Y., Ali, A. M., Almaary, K. S., Mustafa, A. E. Z. M.A., and Husseiny, S. M. (2017). Extracellular biosynthesis of silver nanoparticles using Rhizopus stolonifer. Saudi J. Biol. Sci. 24, 208-216. doi: 10.1016/j.sjbs.2016.02.025

Adeeyo, A. O., and Odiyo, J. O. (2018). Biogenic synthesis of silver nanoparticle from mushroom exopolysaccharides and its potentials in water purification. Open Chem. 5, 64-75. doi: 10.2174/1874842201805010064

Ahluwalia, V., Kumar, J., Sisodia, R., Shakil, N. A., and Walia, S. (2014). Green synthesis of silver nanoparticles by Trichoderma harzianum and their bioefficacy evaluation against Staphylococcus aureus and Klebsiella pneumonia. Ind. Crops Prod. 55, 202-206. doi: 10.1016/j.indcrop.2014.01.026

Ahmad, A., Mukherjee, P., Senapati, S., Mandal, D., Kahn, M. I., Kumar, R., et al. (2003). Extracellular biosynthesis of silver nanoparticles using the fungus Fusarium oxysporum. Colloids Surf. B Biointerfaces 28, 313-318. doi: 10.1016/S0927-7765(02)00174-1

Ahmed, S., Ahmad, M., Swami, B. L., and Ikram, S. (2016). A review on plants extract mediated synthesis of silver nanoparticles for antimicrobial applications: a green expertise. $J A d v$ Res. 7, 17-28. doi: 10.1016/j.jare.2015.02.007

Alghuthaymi, M. A., Almoammar, H., Rai, M., Said-Galiev, E., and AbdElsalam, K. A. (2015). Myconanoparticles: synthesis and their role in phytopathogens management. Biotechnol. Biotechnol. Equip. 29, 221-236. doi: $10.1080 / 13102818.2015 .1008194$

Ashajyothi, C., Praburajeshwar, C., Harish, K. H., and Chandrakanth, K. R. (2016). Investigation of antifungal and anti-mycelium activities using biogenic nanoparticles: an eco-friendly approach. Environ. Nanotechnol. Monit. Manage. 5, 81-87. doi: 10.1016/j.enmm.2016.04.002

Ashrafi, S. J., Rastegar, M. F., Ashrafi, M., Yazdian, F., Pourrahim, R., and Suresh, A. K. (2013). Influence of external factors on the production and morphology of biogenic silver nanocrystallites. J. Nanosci. Nanotechnol. 13, 2295-2301. doi: 10.1166/jnn.2013.6791

Azmath, P., Baker, S., Rakshith, D., and Satish, S. (2016). Mycosynthesis of silver nanoparticles bearing antibacterial activity. Saudi Pharm. J. 24, 140-146. doi: $10.1016 /$ j.jsps.2015.01.008

Baker, S., and Satish, S. (2012). Endophytes: toward a vision in synthesis of nanoparticle for future therapeutic agents. Int. J. Bio Inorg. Hybd. Nanomat. $1,67-77$.

Balaji, D. S., Basavaraja, S., Deshpande, R., Mahesh, D. B., Prabhakar, B. K., and Venkataraman, A. (2009). Extracellular biosynthesis of functionalized silver nanoparticles by strains of Cladosporium cladosporioides fungus. Colloids Surf. B Biointerfaces 68, 88-92. doi: 10.1016/j.colsurfb.2008.09.022

Balakumaran, M. D., Ramachandran, R., and Kalaicheilvan, P. T. (2015). Exploitation of endophytic fungus, Guignardia mangiferae for extracellular synthesis of silver nanoparticles and their in vitro biological activities. Microbiol. Res. 178, 9-17. doi: 10.1016/j.micres.2015.05.009

Ballotin, D., Fulaz, S., Souza, M. L., Corio, P., Rodrigues, A. G., Souza, A. O., et al. (2016). Elucidating protein involvement in the stabilization of the biogenic silver nanoparticles. Nanoscale Res. Lett. 11:313. doi: 10.1186/s11671-016-1538-y

Banu, A. N., and Balasubramanian, C. (2014a). Optimization and synthesis of silver nanoparticles using Isaria fumosorosea against human vector mosquitoes. Parasitol. Res. 113, 3843-3851. doi: 10.1007/s00436-014-4052-0

Banu, A. N., and Balasubramanian, C. (2014b). Mycosynthesis of silver nanoparticles using Beauveria bassiana against dengue vector, Aedes aegypti (Diptera:Culicidae). Parasitol. Res. 113, 2869-77. doi: 10.1007/s00436-013-3656-0

Basavaraja, S., Balaji, S. D., Lagashetty, A., Rajasab, A. H., and Venkataraman, A. (2008). Extracellular biosynthesis of silver nanoparticles using the fungus Fusarium semitectum. Mater. Res. Bull. 43, 1164-1170. doi: 10.1016/j.materresbull.2007.06.020

Baymiller, M., Huang, F., and Rogelj, S. (2017). Rapid one-step synthesis of gold nanoparticles using the ubiquitous coenzyme NADH. Matters. 2017, 1-4. doi: $10.19185 /$ matters.201705000007
Bérdy, J. (2005). Bioactive microbial metabolites. J. Antibiot. 58, 1-26. doi: 10.1038/ja.2005.1

Bhangale, H. G., Bachhav, S. G., Nerkar, D. M., Sarode, K. M., and Patil, D. R. (2019). Study on optical properties of green synthesized silver nanoparticles for surface plasmon resonance. J. Nanosci. Tech. 5, 658-661. doi: $10.30799 /$ jnst.230.19050203

Bhat, M. A., Nayak, B. K., and Nanda, A. (2015). Evaluation of bactericidal activity of biologically synthesized silver nanoparticles from Candida albicans in combination with Ciprofloxacin. Mater Today Proc. 2, 4395-4401. doi: 10.1016/j.matpr.2015.10.036

Birla, S. S., Gaikwad, S. C., Gade, A. K., and Rai, M. K. (2013). Rapid synthesis of silver nanoparticles from Fusarium oxysporum by optimizing physicocultural conditions. Sci World J. 2013:796018. doi: 10.1155/2013/796018

Burduşel, A. C., Gherasim, O., Grumezescu, A. M., Mogoant,ã, L., Ficai, A., and Andronescu, E. (2018). Biomedical applications of silver nanoparticles: an up-to-date overview. Nanomaterials 8:E681. doi: 10.3390/nano8090681

Castro-Longoria, E., Vilchis-Nestor, A. R., and Avalos-Borja, M. (2011). Biosynthesis of silver, gold and bimetallic nanoparticles using the filamentous fungus Neurospora crassa. Colloids Surf. B Biointerfaces 83, 42-48. doi: 10.1016/j.colsurfb.2010.10.035

Chowdhury, S., Basu, A., and Kundu, S. (2014). Green synthesis of protein capped silver nanoparticles from phytopathogenic fungus Macrophomina paseolina. Nanoscale Res. Lett. 9:365. doi: 10.1186/1556-276X-9-365

Costa Silva, L. P., Oliveira, J. P., Keijok, W. J., Silva, A. R., Aguiar, A. R., Guimarães, M. C. C., et al. (2017). Extracellular biosynthesis of silver nanoparticles using the cell-free filtrate of nematophagus fungus Duddingtonia flagans. Int. J. Nanomed. 12, 6373-6381. doi: 10.2147/IJN.S137703

Dakal, T. C., Kumar, A., Majumdar, R. S., and Yadav, V. (2016). Mechanistic basis of antimicrobial actions of silver nanoparticles. Front. Microbiol. 16:1831. doi: $10.3389 /$ fmicb. 2016.01831

Devi, L. S., and Joshi, S. R. (2015). Ultrastructures of silver nanoparticles biosynthesized using endophytic fungi. J. Microsc. Ultrastruct. 3, 29-37. doi: 10.1016/j.jmau.2014.10.004

Du, L., Xu, Q., Huang, M., Xian, L., and Feng, J.-X. (2015). Synthesis of small silver nanoparticles under light radiation by fungus Penicillium oxalicum and its application for the catalytic reduction of methylene blue. Mater. Chem. Phys. 160, 40-47. doi: 10.1016/j.matchemphys.2015.04.003

Durán, N., Marcato, P. D., Alves, O. L., De Souza, G. I. H., and Esposito, E. (2005). Mechanistic aspects of biosynthesis of silver nanoparticles by several Fusarium oxysporum strains. J Nanobiotechnol. 3:8. doi: 10.1186/1477-3155-3-8

Durán, N., Marcato, P. D., Durán, M., Yadav, A., Gade, A., and Rai, M. (2011). Mechanistic aspects in the biogenic synthesis of extracelular metal nanoparticles by peptides, bacteria, fungi and plants. Appl. Microbiol. Biotechnol. 90, 1609-1624. doi: 10.1007/s00253-011-3249-8

Elamawi, R. M., Al-Harbi, R. E., and Hendi, A. A. (2018). Biosynthesis and characterization of silver nanoparticles using Trichoderma longibrachiatum and their effect on phytopathogenic fungi. Egypt J Biol Pest Control 28:28. doi: 10.1186/s41938-018-0028-1

Elgorban, A. M., Aref, S. M., Seham, S. M., Elhindi, K. M., Bahkali, A. H., Sayed, S. R., et al. (2016). Extracellular synthesis of silver nanoparticles using Aspergillus versicolor and evaluation of their activity on plant pathogenic fungi. Mycosphere 7, 844-852. doi: 10.5943/mycosphere/7/6/15

El-Moslamy, S. H., Elkady, M. F., Rezk, A. H., and Abdel-Fattah, Y. R. (2017). Applying Taguchi design and large-scale strategy for mycosynthesis of nanosilver from endophytic Trichoderma harzianum SYA.F4 and its application against phytopathogens. Sci. Rep. 7:45297. doi: 10.1038/srep45297

El-Sonbaty, S. M. (2013). Fungus-mediated synthesis of silver nanoparticles and evaluation of antitumor activity. Cancer Nanotechnol. 4, 73-79. doi: $10.1007 / \mathrm{s} 12645-013-0038-3$

Fátima, F., Verma, S. R., Pathak, N., and Bajpai, P. (2016). Extracellular mycosynthesis of silver nanoparticles and their microbicidal activity. J. Glob. Antimicrob. Resist. 7, 88-92. doi: 10.1016/j.jgar.2016.07.013

Fayaz, A. M., Balaji, K., Kalaichelvan, P. T., and Venkatesan, R. (2009). Fungal based synthesis of silver nanoparticles-an effect of temperature on the size of particles. Colloids Surf. B Biointerfaces. 74, 123-126. doi: 10.1016/j.colsurfb.2009.07.002

Gade, A. K., Bonde, P., Ingle, A. P., Marcato, P. D., Durán, N., and Rai, M. K. (2008). Exploitation of Aspergillus niger for synthesis of silver 
nanoparticles. J. Biobased Mater. Bioenergy. 2, 243-247. doi: 10.1166/jbmb.20 08.401

Gaikwad, S., Ingle, A., Gade, A., Rai, M., Falanga, A., Incoronato, N., et al. (2013). Antiviral activity of mycosynthesized silver nanoparticles against herpes simplex virus and human parainfluenza virus type 3. Int. J. Nanomed. 8, 4303-4314. doi: 10.2147/IJN.S50070

Gajbhiye, M., Kesharwani, J., Ingle, A., Gade, A., and Rai, M. (2009). Fungus-mediated synthesis of silver nanoparticles and their activity against pathogenic fungi in combination with fluconazole. Nanomedicine 5, 382-386. doi: 10.1016/j.nano.2009.06.005

Gherbawy, Y. A., Shalaby, I. M., El-Sadek, M. S. A., Elhariry, H. M., and Banaja, A. A. (2013). The anti-fasciolasis properties of silver nanoparticles produced by Trichoderma harzianum and their improvement of the anti-fasciolasis drug triclabendazole. Int. J. Mol. Sci. 14, 21887-21898. doi: 10.3390/ijms141121887

Gholami-Shabani, M., Akbarzadeh, A., Norouzian, D., Amini, A., GholamiShabani, Z., Imani, A., et al. (2014). Antimicrobial activity and physical characterization of silver nanoparticles green synthesized using nitrate reductase from Fusarium oxysporum. Appl. Biochem. Biotechnol. 172, 4084-4098. doi: 10.1007/s12010-014-0809-2

Gole, A., Dash, C., Ramakrishnan, V., Sainkar, S. R., Mandale, A. B., Rao, M., et al. (2001). Pepsin-gold colloid conjugates: preparation, characterization, and enzymatic activity. Langmuir 17, 1674-1679. doi: 10.1021/la001164w

Gopinath, V., Mubarakali, D., Priyadarshini, S., Priyadarsshini, M., Thajuddin, N., and Velusamy, P. (2012). Biosynthesis of silver nanoparticles from Tribulus terrestris and its antimicrobial activity: a novel biological approach. Colloids Surf. B Biointerfaces 96, 69-74. doi: 10.1016/j.colsurfb.2012.03.023

Gudikandula, K., Vadapally, P., and Charya, M. A. S. (2017). Biogenic synthesis of silver nanoparticles from white rot fungi: their characterization and antibacterial studies. Open Nano 2, 64-78. doi: 10.1016/j.onano.2017.07.002

Guilger, M., Pasquoto-Stigliani, T., Bilesky-Jose, N., Grillo, R., Abhilash, P. C., Fraceto, L. F., et al. (2017). Biogenic silver nanoparticles based on Trichoderma harzianum: synthesis, characterization, toxicity evaluation and biological activity. Sci. Rep. 7:44421. doi: 10.1038/srep44421

Gupta, R. K., Kumar, V., Gundampati, R. K., Malviya, M., Hasan, S. H., Jagannadham, M. V., et al. (2017). Biosynthesis of silver nanoparticles from the novel strain of Streptomyces Sp. BHUMBU-80 with highly efficient electroanalytical detection of hydrogen peroxide and antibacterial activity. J. Environ. Chem. Eng. 5, 5624-5635. doi: 10.1016/j.jece.2017.09.029

Gurunathan, S., Kalishwaralal, K., Vaidyanathan, R., Deepak, V., Pandian, S. R. K., Muniyand, J., et al. (2009). Biosynthesis, purification and characterization of silver nanoparticles using Escherichia coli. Colloids Surf. B Biointerfaces 74, 328-335. doi: 10.1016/j.colsurfb.2009.07.048

Hamedi, S., Ghaseminezhad, M., Shokrollahzadeh, S., and Shojaosadati, S. A. (2017). Controlled biosynthesis of silver nanoparticles using nitrate reductase enzyme induction of filamentous fungus and their antibacterial evaluation. Artif. Cells Nanomed. Biotechnol. 45, 1588-1596. doi: 10.1080/21691401.2016.1267011

Hietzschold, S., Walter, A., Davis, C., Taylor, A. A., and Sepunaru, L. (2019). Does nitrate reductase play a role in silver nanoparticle synthesis? Evidence for NADPH as the sole reducing agent. ACS Sustain. Chem. Eng. 7, 8070-8076. doi: 10.1021/acssuschemeng.9b00506

Hu, C. J., Zhang, L., Aryal, S., Cheung, C., Fang, R. H., and Zhang, L. (2011). Erythrocyte membrane-camouflaged polymeric nanoparticles as a biomimetic delivery platform. Proc. Natl. Acad. Sci. U.S.A. 108, 10980-10985. doi: 10.1073/pnas.1106634108

Husseiny, S. M., Salah, T. A., and Anter, H. A. (2015). Biosynthesis of size controlled silver nanoparticles by Fusarium oxysporum, their antibacterial and antitumoral activities. Beni Suef Univer. J. Basic Appl. Sci. 4, 225-31. doi: 10.1016/j.bjbas.2015.07.004

Ibrahim, H. M. M., and Hassan, M. S. (2016). Characterization and antimicrobial properties of cotton fabric loaded with green synthesized silver nanoparticles. Carbohydr. Polym. 151, 841-850. doi: 10.1016/j.carbpol.2016.05.041

Iravani, S., Korbekandi, H., Mirmohammadi, S. V., and Zolfaghari, B. (2014). Synthesis of silver nanoparticles: chemical, physical and biological methods. Res. Pharm. Sci. 9, 385-406.

Ishida, K., Cipriano, T. F., Rocha, G. M., Weissmüller, G., Gomes, F., Miranda, K., et al. (2014). Silver nanoparticle production by the fungus Fusarium oxysporum: nanoparticle characterisation and analysis of antifungal activity against pathogenic yeasts. Mem. Inst. Oswaldo Cruz. 109, 220-228. doi: 10.1590/0074-0276130269

Kamil, D., Prameeladevi, T., Ganesh, S., Prabakharan, N., Nareshkumar, R., and Thomas, S. P. (2017). Green synthesis of silver nanoparticles by entomopathogenic fungus Beauveria bassiana and their bioefficacy against mustard aphid (Lipaphis erysimi Kalt.). Indian J. Exp. Biol. 55, 555-561.

Kaviya, S., Santhanalakshmi, J., and Viswanathan, B. (2011). Green synthesis of silver nanoparticles using Polyalthia longifolia leaf extract along with D-sorbitol: study of antibacterial activity. J. Nanotechnol. 2011:152970. doi: $10.1155 / 2011 / 152970$

Khan, N. T., Khan, M. J., Jameel, J., Jameel, N., and Rheman, S. U. A. (2017). An overview: biological organisms that serves as nanofactories for metallic nanoparticles synthesis and fungi being the most appropriate. Bioceram Dev. Appl. 7:101. doi: 10.4172/2090-5025.1000101

Khandel, P., and Shahi, S. K. (2018). Mycogenic nanoparticles and their bioprospective applications:current status and future challenges. J. Nanostr. Chem. 8, 369-391. doi: 10.1007/s40097-018-0285-2

Kim, S. H., Lee, H. S., Ryu, D. S., Choi, S. J., and Lee, D. S. (2011). Antibacterial activity of silver-nanoparticles against Staphylococcus aureus and Escherichia coli. Korean J. Microbiol. Biotechnol. 39, 77-85.

Kim, S. W., Jung, J. H., Lamsal, K., Kim, Y. S., Min, J. S., and Lee, Y. S. (2012). Antifungal effects of silver nanoparticles (AgNPs) against various plant pathogenic fungi. Mycobiology 40, 53-58. doi: 10.5941/MYCO.2012.40.1.053

Korbekandi, H., Ashari, Z., Iravani, S., and Abbasi, S. (2013). Optimization of biological synthesis of silver nanoparticles using Fusarium oxysporum. Iran. J. Pharm. Res. 12, 289-298.

Kumar, S. A., Abyaneh, M. K., Gosavi, S. W., Kulkarni, S. K., Pasricha, N., Ahmad, A., et al. (2007). Nitrate reductase-mediated synthesis of silver nanoparticles from $\mathrm{AgNO}_{3}$. Biotechnol. Lett. 29, 439-445. doi: 10.1007/s10529-006-9256-7

Lee, S. H., and Jun, B. H. (2019). Silver nanoparticles: synthesis and application for nanomedicine. Int. J. Mol. Sci. 20:E865. doi: 10.3390/ijms20040865

Li, W., Xie, X., Shi, Q., Zeng, H., Ou-Yang, Y., and Chen, Y. (2010). Antibacterial activity and mechanism of silver nanoparticles on Escherichia coli. Appl. Microbiol. Biotechnol. 85, 1115-1122. doi: 10.1007/s00253-009-2159-5

Liang, M., Wei, S., Jian-Xin, L., Xiao-Xi, Z., Zhi, H., Wen, L., et al. (2017). Optimization for extracellular biosynthesis of silver nanoparticles by Penicillium aculeatum Sul and their antimicrobial activity and cytotoxic effect compared with silver ions. Mater. Sci. Eng. C 77, 963-971. doi: 10.1016/j.msec.2017.03.294

Loo, Y. Y., Rukayadil, Y., Nor-Khaizura, M. A. R., Kuan, C. H., Chieng, B. W., Nishibuchi, M., et al. (2018). In vitro antimicrobial activity of green synthesized silver nanoparticles against selected gram-negative foodborne pathogens. Front. Microbiol. 9:1555. doi: 10.3389/fmicb.2018.01555

Lu, Z., Rong, K., Li, J., Yang, H., and Chen, R. (2013). Size-dependent antibacterial activities of silver nanoparticles against oral anaerobic pathogenic bacteria. $J$. Mater. Sci. 24, 1465-1471. doi: 10.1007/s10856-013-4894-5

Mekkawy, A. I., El-Mokhtar, M. A., Nafady, N. A., Yousef, N., Hamad, M. A., El-Shanawany, S. M., et al. (2017). In vitro and in vivo evaluation of biologically synthesized silver nanoparticles for topical applications: effect of surface coating and loading into hydrogels. Int. J. Nanomed. 12, 759-777. doi: 10.2147/IJN.S124294

Metuku, R. P., Pabba, S., Burra, S., Hima Bindu N, S. V. S. S. S. L., Gudikandula, K., Singara and Charya, M. A. (2014). Biosynthesis of silver nanoparticles from Schizophyllum radiatum HE 863742.1: their characterization and antimicrobial activity. 3 Biotech 4, 227-234. doi: 10.1007/s13205-013-0138-0

Mishra, S., and Singh, H. B. (2015). Biosynthesized silver nanoparticles as a nanoweapon against phytopathogens: exploring their scope and potential in agriculture. Appl. Microbiol. Biotechnol. 99, 1097-1107. doi: 10.1007/s00253-014-6296-0

Moazeni, M., Rashidi, N., Shahverdi, A. R., Noorbakhsh, F., and Rezaie, S. (2012). Extracellular production of silver nanoparticles by using three common species of dermatophytes: Trichophyton rubrum, Trichophyton mentagrophytes and Microsporum canis. Iran. Biomed. J. 16, 52-58. doi: 10.6091/IBJ.1001.2012

Mohanta, Y. K., Nayak, D., Biswas, K., Singdevsachan, S. K., Abd_Allah, E. F., Hashem, A., et al. (2018). Silver nanoparticles synthesized using wild mushroom show potential antimicrobial activities against food borne pathogens. Molecules 23, 1-18. doi: 10.3390/molecules230 30655 
Molnár, Z., Bódai, V., Szakacs, G., Erdélyi, B., Fogarassy, Z., Sáfrán, G., et al. (2018). Green synthesis of gold nanoparticles by thermophilic filamentous fungi. Sci. Rep. 8:3943. doi: 10.1038/s41598-018-22112-3

Morones, J. R., Elichiguerra, J. L., Camacho, A., Holt, K., Kouri, J. B., Ramírez, J. T., et al. (2005). The bactericidal effect of silver nanoparticles. Nanotechnology 16, 2346-2353. doi: 10.1088/0957-4484/16/10/059

Mout, R., Moyano, D. F., Rana, S., and Rotello, V. M. (2012). Surface functionalization of nanoparticles for nanomedicine. Chem. Soc. Rev. 41, 2539-2544. doi: 10.1039/c2cs15294k

Nagajyothi, P. C., Sreekanth, T. V. M., Lee, J., and Lee, K. D. (2014). Mycosynthesis: antibacterial, antioxidant and antiproliferative activities of silver nanoparticles synthesized from Inonotus obliquus (Chaga mushroom) extract. J. Photochem. Photobiol. B 130, 299-304. doi: 10.1016/j.jphotobiol.2013.11.022

Naqvi, S. Z. H., Kiran, U., Ali, M. I., Jamal, A., Hameed, A., Ahmed, S., et al. (2013). Combined efficacy of biologically synthesized silver nanoparticles and different antibiotics against multidrug-resistant bacteria. Int. J. Nanomed. 8, 3187-3195. doi: $10.2147 /$ IJN.S49284

Nayak, B. K., Nanda, A., and Prabhakar, V. (2018). Biogenic synthesis of silver nanoparticle from wasp nest soil fungus, Penicillium italicum and its analysis against multi drug resistance pathogens. Biocatal. Agric. Biotechnol. 16, 412-418. doi: 10.1016/j.bcab.2018.09.014

Nayak, R. R., Pradhan, N., Behera, D., Pradhan, K. M., Mishra, S., Sukla, L. B., et al. (2011). Green synthesis of silver nanoparticle by Penicillium purpurogenum NPMF: the process and optimization. J. Nanopart. Res. 13, 3129-3137. doi: 10.1007/s11051-010-0208-8

Netala, V. R., Bethu, M. S., Pushpalatah, B., Baki, V. B., Aishwarya, S., Rao, J. V., et al. (2016). Biogenesis of silver nanoparticles using endophytic fungus Pestalotiopsis microspora and evaluation of their antioxidant and anticancer activities. Int. J. Nanomed. 11, 5683-5696. doi: 10.2147/IJN.S112857

Ottoni, C. A., Simões, M. F., Fernandes, S., Santos, J. G., Silva, E. S., Souza, R. F. B., et al. (2017). Screening of filamentous fungi for antimicrobial silver nanoparticles synthesis. AMB Express 7:31. doi: 10.1186/s13568-017-0332-2

Owaid, M. N., Raman, J., Lakshmanan, H., Al-Saeedi, S. S. S., Sabaratnam, V., and Abed, I. A. (2015). Mycosynthesis of silver nanoparticles by Pleurotus cornucopiae var. citrinopileatus and its inhibitory effects against Candida sp. Mater. Lett. 153, 186-190. doi: 10.1016/j.matlet.2015.04.023

Pereira, L., Dias, N., Carvalho, J., Fernandes, S., Santos, C., and Lima, N. (2014). Synthesis, characterization and antifungal activity of chemically and fungalproduced silver nanoparticles against Trichophyton rubrum. J. Appl. Microbiol. 117, 1601-1613. doi: 10.1111/jam.12652

Phanjom, P., and Ahmed, G. (2017). Effect of different physicochemical conditions on the synthesis of silver nanoparticles using fungal cell filtrate of Aspergillus oryzae (MTCC No. 1846) and their antibacterial effects. Adv. Nat. Sci. Nanosci. Nanotechnol. 8, 1-13. doi: 10.1088/2043-6254/aa92bc

Prabhu, S., and Poulose, E. K. (2012). Silver Nanoparticles: mechanism of antimicrobial action, synthesis, medical applications, and toxicity effects. Int. Nano Lett. 2:32. doi: 10.1186/2228-5326-2-32

Qian, Y., Yu, H., He, D., Yang, H., Wang, W., Wan, X., et al. (2013). Biosynthesis of silver nanoparticles by the endophytic fungus Epicoccum nigrum and their activity against pathogenic fungi. Bioprocess Biosyst. Eng. 36, 1613-1619. doi: 10.1007/s00449-013-0937-z

Qidwai, A., Pandey, A., Kumar, R., Shukla, S. K., and Dikshit, A. (2018). Advances in biogenic nanoparticles and the mechanisms of antimicrobial effects. Indian J. Pharm. Sci. 80, 592-603. doi: 10.4172/pharmaceutical-sciences.1000398

Rai, M., Kon, K., Ingle, A., Duran, N., Galdiero, S., and Galdiero, M. (2014). Broad-spectrum bioactivities of silver nanoparticles: the emerging trends and future prospects. Appl. Microbiol. Biotechnol. 98, 1951-1961. doi: $10.1007 /$ s00253-013-5473-x

Rai, M., Yadav, A., and Gade, A. (2009). Silver nanoparticles as a new generation of antimicrobials. Biotechnol. Adv. 27, 76-83. doi: 10.1016/j.biotechadv.2008.09.002

Rajput, S., Werezuk, R., Lange, R. M., and Mcdermott, M. T. (2016). Fungal isolate optimized for biogenesis of silver nanoparticles with enhanced colloidal stability. Langmuir 32, 8688-8697. doi: 10.1021/acs.langmuir.6b01813

Raman, J., Reddy, G. R., Lakshmanan, H., Selvaraj, V., Gajendran, B., Nanjian, R., et al. (2015). Mycosynthesis and characterization of silver nanoparticles from Pleurotus djamor var. roseus and their in vitro cytotoxicity effect onPC3 cells. Process Biochem. 50, 140-147. doi: 10.1016/j.procbio.2014.11.003
Rani, R., Sharma, D., Chaturvedi, M., and Yadav, J. P. (2017). Green synthesis, characterization and antibacterial activity of silver nanoparticles of endophytic fungi Aspergillus terreus. J. Nanomed. Nanotechnol. 8:4. doi: 10.4172/2157-7439.1000457

Reidy, B., Haase, A., Luch, A., and Dawson, K. (2013). Mechanisms of silver nanoparticle release, transformation and toxicity: a critical review of current knowledge and recommendations for future studies and applications. Materials 6, 2295-2350. doi: 10.3390/ma6062295

Rheder, D. T., Guilger, M., Bilesky-José, N., Germano-Costa, T., PasquotoStigliani, T., Gallep, T. B. B., et al. (2018). Synthesis of biogenic silver nanoparticles using Althaea officinalis as reducing agent: evaluation of toxicity and ecotoxicity. Sci Rep. 8:12397. doi: 10.1038/s41598-018-30317-9

Rodrigues, A. G., Ping, L. Y., Marcato, P. D., Alves, O. L., Silva, M. C. P., Ruiz, R. C., et al. (2013). Biogenic antimicrobial silver nanoparticles produced by fungi. Appl. Microbiol. Biotechnol. 97, 775-782. doi: 10.1007/s00253-0124209-7

Rose, G. K., Soni, R., Rishi, P., and Soni, S. K. (2019). Optimization of the biological synthesis of silver nanoparticles using Penicillium oxalicum GRS-1 and their antimicrobial effects against common food-borne pathogens. Green Process Synth. 8, 144-156. doi: 10.1515/gps-2018-0042

Sabri, M. A., Umer, A., Awan, G. H., Hassan, M. F., and Hasnain, A. (2016). Selection of suitable biological method for the synthesis of silver nanoparticles. Nanomater Nanotechnol. 6, 1-20. doi: 10.5772/62644

Saxena, J., Sharma, P. K., Sharma, M. M., and Singh, A. (2016). Process optimization for green synthesis of silver nanoparticles by Sclerotinia sclerotiorum MTCC 8785 and evaluation of its antibacterial properties. Springerplus 5:861. doi: 10.1186/s40064-016-2558-x

Shahzad, A., Saeed, H., Iqtedar, M., Hussain, S. Z., Kaleem, A., and Abdullah, R. (2019). Size-controlled production of silver nanoparticles by Aspergillus fumigatus BTCB10: likely antibacterial and cytotoxic effects. J. Nanomater. 2019:5168698. doi: 10.1155/2019/5168698

Shrivastava, S., Bera, T., Roy, A., Singh, G., Ramachandrarao, P., and Dash, D. (2007). Characterization of enhanced antibacterial effects of novel silver nanoparticles. Nanotechnology 18:225103. doi: 10.1088/0957-4484/18/22/225103

Singh, D., Rathod, V., Ninganagouda, S., Hiremath, J., Singh, A. K., and Mathew, J. (2014). Optimization and characterization of silver nanoparticle by endophytic fungi Penicillium sp. isolated from Curcuma longa (Turmeric) and application studies against MDR E. coli and S. aureus. Bioinorg. Chem. Appl. 2014:408021. doi: $10.1155 / 2014 / 408021$

Singh, R., Shedbalkar, U. U., Wadhwani, S. A., and Chopade, B. A. (2015). Bacteriagenic silver nanoparticles: synthesis, mechanism, and applications. Appl. Microbiol. Biotechnol. 99, 4579-4593. doi: 10.1007/s00253-015$6622-1$

Singh, T., Jyoti, K., Patnaik, A., Singh, A., Chauhan, R., and Chandel, S. S. (2017). Biosynthesis, characterization and antibacterial activity of silver nanoparticles using an endophytic fungal supernatant of Raphanus sativus. J. Genet. Eng. Biotechnol. 15, 31-39. doi: 10.1016/j.jgeb.2017.04.005

Sintubin, L., Windt, W. D., Dick, J., Mast, J., Ha, D. V. D., Verstraete, W., et al. (2009). Lactic acid bacteria as reducing and capping agent for the fast and efficient production of silver nanoparticles. Appl. Microbiol. Biotechnol. 84, 741-749. doi: 10.1007/s00253-009-2032-6

Sriram, M. I., Kanth, S. B. M., Kalishwaralal, K., and Gurunathan, S. (2010). Antitumor activity of silver nanoparticles in Dalton's lymphoma ascites tumor model. Int. J. Nanomed. 5, 753-762. doi: 10.2147/IJN.S11727

Sundaravadivelan, C., and Padmanabhan, M. N. (2014). Effect of mycosynthesized silver nanoparticles from filtrate of Trichoderma harzianum against larvae and pupa of dengue vector Aedes aegypti L. Environ. Sci. Pollut. Res. 21, 4624-4633. doi: 10.1007/s11356-013-2358-6

Thakkar, K. N., Mhatre, S. S., and Parikh, R. Y. (2010). Biological synthesis of metallic nanoparticles. Nanomedicine 6, 257-262. doi: 10.1016/j.nano.2009.07.002

Vahabi, K., Mansoori, G. A., and Karimi, S. (2011). Biosynthesis of silver nanoparticles by fungus Trichoderma reesei. Insci. J. 1, 65-79. doi: 10.5640/insc. 010165

Velusamy, P., Kumar, G. V., Jeyanthi, V., Das, J., and Pachaiappan, R. (2016). Bio-inspired green nanoparticles: synthesis, mechanism, and antibacterial application. Toxicol. Res. 32, 95-102. doi: 10.5487/TR.2016.32.2.095 
Xue, B., He, D., Gao, S., Wang, D., Yokoyama, K., and Wang, L. (2016). Biosynthesis of silver nanoparticles by the fungus Arthroderma fulvum and its antifungal activity against genera of Candida, Aspergillus and Fusarium. Int. J. Nanomed. 11, 1899-1906. doi: 10.2147/IJN.S98339

Yahyaei, B., and Pourali, P. (2019). One step conjugation of some chemotherapeutic drugs to the biologically produced gold nanoparticles and assessment of their anticancer effects. Sci. Rep. 9:10242. doi: 10.1038/s41598-019-46602-0

Zhang, X. F., Liu, Z. G., Shen, W., and Gurunathan, S. (2016). Silver nanoparticles: synthesis, characterization, properties, applications, and therapeutic approaches. Int. J. Mol. Sci. 17:E1534. doi: 10.3390/ijms170 91534

Zielonka, A., and Klimek-Ochab, M. (2017). Fungal synthesis of sizedefined nanoparticles. Adv. Nat. Sci.: Nanosci. Nanotechnol. 8:043001. doi: 10.1088/2043-6254/aa84d4
Zomorodian, K., Pourshahid, S., Sadatsharifi, A., Mehryar, P., Pakshir, K., Rahimi, M. J., et al. (2016). Biosynthesis and characterization of silver nanoparticles by Aspergillus species. Biomed Res. Int. 2016:5435397. doi: 10.1155/2016/5435397

Conflict of Interest: The authors declare that the research was conducted in the absence of any commercial or financial relationships that could be construed as a potential conflict of interest.

Copyright $\odot 2019$ Guilger-Casagrande and Lima. This is an open-access article distributed under the terms of the Creative Commons Attribution License (CC BY). The use, distribution or reproduction in other forums is permitted, provided the original author(s) and the copyright owner(s) are credited and that the original publication in this journal is cited, in accordance with accepted academic practice. No use, distribution or reproduction is permitted which does not comply with these terms. 